\title{
Physico-chemical conditions of four calc-alkaline granitoid plutons of Chhotanagpur Gneissic Complex, eastern India: Tectonic implications
}

\author{
B Goswami*, P Roy, A Basak, S Das and C Bhattacharyya \\ Department of Geology, University of Calcutta, 35 Ballygunge Circular Road, Kolkata 700 019, India. \\ *Corresponding author. e-mail: bapigoswami69@gmail.com
}

MS received 28 February 2017; revised 3 March 2018; accepted 5 March 2018; published online 26 October 2018

Petrography and mineralogy of four calc-alkaline granitoid plutons Agarpur, Sindurpur, Raghunathpur and Sarpahari located from west to east of northern Purulia of Chhotanagpur Gneissic Complex, eastern India, are investigated. The plutons, as a whole, are composed of varying proportions of Qtz-Pl-Kfs-Bt-Hbl $\pm \mathrm{Px}-\mathrm{Ttn}-\mathrm{Mag}-\mathrm{Ap}-\mathrm{Zrn} \pm \mathrm{Ep}$. The composition of biotite is consistent with those of calc-alkaline granitoids. Hornblende-plagioclase thermometry, aluminium-in-hornblende barometry and the assemblage sphene-magnetite-quartz were used to determine the $P, T$ and $f_{\mathrm{O}_{2}}$ during the crystallisation of the parent magmas in different plutons. The plutons are crystallised under varying pressures $(6.2-2.4 \mathrm{kbar})$ and a wide range of temperatures $\left(896-718^{\circ} \mathrm{C}\right)$ from highly oxidised magmas $\left(\log f_{\mathrm{O}_{2}}-11.2\right.$ to -15.4 bar). The water content of the magma of different plutons varied from 5.0 to 6.5 wt\%, consistent with the calc-alkaline nature of the magma. Calc-alkaline nature, high oxygen fugacity and high $\mathrm{H}_{2} \mathrm{O}_{\text {melt }}$ suggest that these plutons were emplaced in subduction zone environment. The depths of emplacement of these plutons seem to increase from west to east. Petrologic compositions of these granitoids continuously change from enderbite (opx-tonalite: Sarpahari) in the east to monzogranite (Raghunathpur) to syenogranite (Sindurpur) to alkali feldspar granite (Agarpur) in the west. The water contents of the parental magmas of different plutons also increase systematically from east to west. No substantial increase in the depth of emplacement is found in these plutons lying south and north of the major shear zone passing through the study area suggesting the strike-slip nature of the east-west shear zone.

Keywords. Calc-alkaline granitoids; mineral chemistry; intensive parameters; Chhotanagpur Gneissic Complex; eastern India.

\section{Introduction}

The mineral assemblages (quartz-alkali feldsparplagioclase-biotite-amphibole-sphe ne-magnetite and/or ilmenite) and evolving conditions of the calc-alkaline magma during crystallisation are closely related (Speer 1987; Vyhnal et al. 1991; Ague 1997). Particularly, the compositions of hornblendes and biotites are related to pressure and temperature and oxygen fugacity of the magma. While total Al-in-hornblende is a function of pressure (Hammarstrom and Zen 1986; Vyhnal et al. 1991; Schmidt 1992; Anderson 1996; Mutch et al. 2016), Ti-in-hornblende (Otten 1984) and the compositions of coexisting hornblendeplagioclase (Holland and Blundy 1994) are related to the temperature of the magma. Further, compositions of biotite, sphene (titanite) and $\mathrm{Fe}-\mathrm{Ti}$ 
oxides are important for the calculation of oxygen fugacity (Wones 1989). Compositions of amphibole and biotite are also related to the water content of the magma (Ridolfi and Renzulli 2012). On the other hand, the determination of pressure and temperatures of the calc-alkaline plutons is important for unravelling the evidence for the ascent (or descent) of exposed crustal sections.

Although in the Proterozoic Chhotanagpur Gneissic Complex (CGC) granitoids are the most important rock groups with a wide distribution of calc-alkaline granitoids, only few papers that dealt with the mineralogical aspects of these granitoids have so far been published (Ghose 1983, 1992).

This contribution focuses on four calc-alkaline granitoid plutons (Agarpur, Sindurpur, Raghunathpur and Sarpahari) exposed in northeastern Purulia, West Bengal. The occurrences of these plutons are restricted between the North Purulia Shear Zone (NPSZ) and the northen megalineament (shear zone) and immediate south of the NPSZ. The aims of this paper are to: (i) describe the mineral-chemical evolution of the above four plutons, (ii) decipher the physico-chemical conditions (pressure and temperature of crystallisation and oxygen fugacity and water content) that prevailed during the crystallisation of magmas, and (iii) discuss the implications of the data on the geotectonic interpretation of the plutons of the northern part of Purulia.

\section{Geologic setting}

Eastern Indian shield comprises the CGC (covering $\sim 100,000 \mathrm{~km}^{2}$ area) in the north, the Singhbhum craton in the south and the eastwest (E-W) trending North Singhbhum Mobile Belt (NSMB) between these two (figure 1A). The southern boundary of the CGC with the NSMB is tentatively marked by the South Purulia Shear Zone (Basu 1993). The northern and eastern margins of the CGC are covered by the GangaBrahmaputra alluvial deposits (figure 1A). In the west, the CGC is separated from the Central Indian Tectonic Zone by younger Gondwana sediments.

The CGC is characterised by widespread Palaeo- to Neo-Proterozoic predominant granitoid gneisses and migmatites with older enclaves of metapelitic gneisses (khondalites), amphibolites, calc-granulites, quartzites, charnockites, leptynites and mafic granulites, and younger intrusives of granites, pegmatites, norites, anorthosites and alkaline rocks (Mahadevan 2002). Ghose (1983) and Banerji (1991) classified the CGC into several lithostratigraphic units, while Singh (1998) argued that the formations within the CGC show gradational changes and do not, in general, 'obey the law of superposition' and hence suggested these as 'lithodemic' group.

A part of the study area (figure 1b) lying in the northern part of Purulia district, West Bengal (eastern part of CGC) was described by Sen (1953, 1956, 1959), Mitra (1992), Goswami and Bhattacharyya (2008, 2014) and Maji et al. (2008). Two prominent lineaments: (i) the nearly E-W trending NPSZ and (ii) and ENE trending lineament (known as the northern megalineament) lying to the north of (i) pass through the area. The migmatitic/composite granitoid gneisses country occupying the northern side of the northern megalineament and also the southern side of the NPSZ contain enclaves of khondalites, marbles, calc-silicate schists/gneisses, para- and ortho-amphibolites belonging to amphibolite facies. However, the leptynitic country in between the two lineaments contains minor patches of migmatites, basic granulites, charnockitic rocks and calc-silicate rocks representing amphibolite and granulite facies. Several intrusive bodies of granitoids intrude into the leptynitic country. These granitoid intrusions have been traditionally viewed as Mesoproterozoic in age. The four representative plutons which are studied include the Agarpur, Sindurpur, Raghunathpur and Sarpahari intrusions, of which, three are located between the E-W trending NPSZ and the northern megalineament while the Sindurpur pluton is located south of NPSZ (figure 1B).

Grey-coloured biotite granitoid gneiss, often garnetiferous, is the major component of migmatitic granitoid gneisses country. Enclaves of migmatitic granitoid gneiss sometimes occur within the intrusive granitoids. Numerous lensoidal metasedimentary enclaves of garnet-sillimanite gneiss (khondalite), calc granulites, amphibolite, mica schist, etc., are noticed within the migmatitic granitoid gneiss. The contact of the metasedimentary enclaves and the migmatitic granitoid gneiss is gradational. Long axes of the enclaves are aligned parallel to the regional foliation. Pyroxene granulite, charnockitic rocks, nepheline syenite gneisses and orthoamphibolites are also interpreted to have igneous protolith (Goswami and Bhattacharyya 2008). 

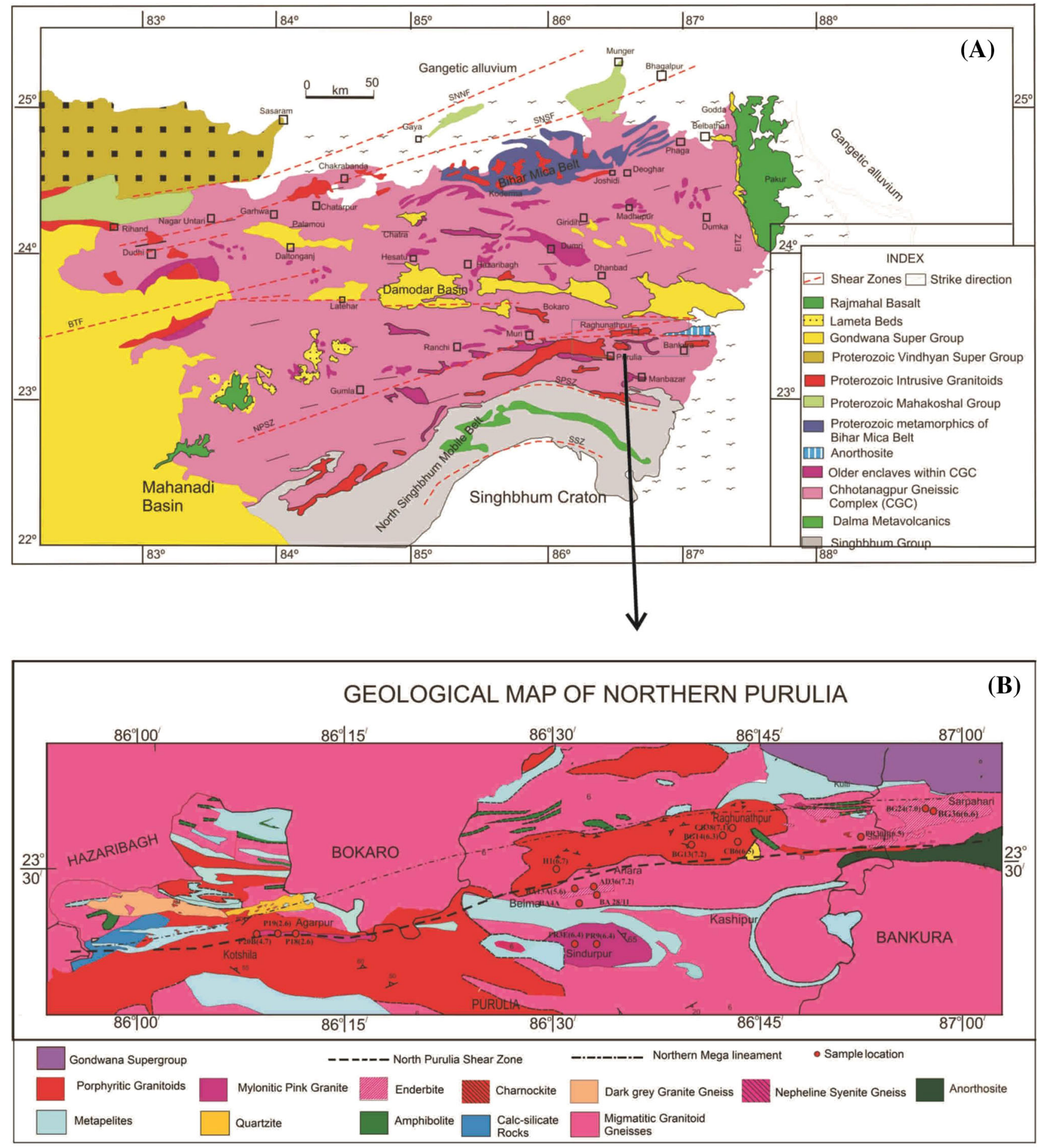

Figure 1. (A) Generalised geological map of the CGC showing the distribution of Archean-Proterozoic metasedimentary enclaves and granitic intrusives. Proterozoic Dalma lava in the Singhbhum mobile belt, the Cretaceous Rajmahal volcanics and Mesozoic Gondwana basins associated with the Damodar Graben are shown for reference. (B) Simplified geological map of the area of study in northern Purulia.

Major structural grains are represented by a dominant foliation trending $\mathrm{E}-\mathrm{W}$ to $\mathrm{NE}-\mathrm{SW}$ with a northerly low-to-moderate $\operatorname{dip}\left(20^{\circ}-40^{\circ}\right)$. The ENE-WSW alignment of the intrusive granites is more or less parallel to the trend of the major shear zones.
The rocks of the area bear signatures of at least three phases of deformations $\left(\mathrm{D}_{1}, \mathrm{D}_{2}\right.$ and $\left.\mathrm{D}_{3}\right)$. Nearly parallel $S_{1}$ and $S_{2}$ foliations are discernible in quartzites and grey biotite granitoid gneisses. $\mathrm{S}_{1}$ is the dominant foliation of the area. $\mathrm{S}_{1}$ is axial planar to the tight, appressed intrafolial $\mathrm{D}_{1}$ folds 
(figure $2 \mathrm{~A}$ ). $\mathrm{D}_{2}$ folds are defined by form surface of a set of gneissic banding $\left(\mathrm{S}_{1}\right)$. In mesoscopic scale, $\mathrm{D}_{1}$ minor folds are highly plunging or nearly reclined. $\mathrm{D}_{1}$ folds are rarely encountered in intrafolial layers of biotite granitoid gneiss, quartzite and calc-silicate rocks. $\mathrm{D}_{2}$ folds are tight to close, low plunging and overturned (figure 2B). The shear movement represents the $\mathrm{D}_{3}$-deformation. Granite mylonites, augen gneisses and leptynites characterised by the formation of ribbon quartz occur all along the NPSZ and northern megalineament. The strike-slip movement with a sinistral sense on the plan is the dominant nature of NPSZ (figure 2C).

The basic granulites show weak foliation $\left(\mathrm{S}_{1}\right)$, defined by the preferred orientation of orthopyroxene, which was subsequently folded by $D_{2}$. Similarly, the long dimension of rod-shaped sillimanites in garnet-sillimanite gneisses got folded during $\mathrm{D}_{2}$. This suggests that the metamorphism in the upper amphibolite to granulite grade was attained during $\mathrm{D}_{1}$-deformation. The country rock attained granulite facies in the eastern part of the study area, i.e., around the Sarpahari pluton. The grade of metamorphism gradually decreased towards the west and reached amphibolite facies around the Agarpur pluton (Goswami and Bhattacharyya 2008).

The intrusion/injection of enderbite (opxtonalite) and/or charnockite (opx-granite), sensu stricto, along the $\mathrm{S}_{1}$ plane of the basic granulites (figures 2B and 2D) and migmatitic gneisses is commonly noticed. Primary banding of enderbite of the Sarpahari pluton was folded during $\mathrm{D}_{2}$-deformation (figure $2 \mathrm{E}$ ). The pluton emplaced before $\mathrm{D}_{2}$-deformation.

The long axis of the Raghunathpur pluton is ENE-WSW. The porphyritic granitoids contain strongly aligned euhedral crystals of pinkish Kfeldspar megacrysts (figure $2 \mathrm{~F}$ ) which is interpreted to be due to magmatic flow (Goswami and Bhattacharyya 2014). The long dimension of feldspar grains ranges from 3 to $10 \mathrm{~cm}$. The flow foliation of porphyritic granitoids is deflected around the xenoliths of basic granulite (figure $2 \mathrm{G}$ ). Along the northern and southern boundaries of the pluton, microcline megacrysts are lensoid in shape and ferromagnesian minerals tend to warp around them giving rise to augen structures (figure $2 \mathrm{H}$ ). This feature is interpreted to be due to shearing along the boundaries.

The Sindurpur pluton occurs as a very prominent $\mathrm{E}-\mathrm{W}$ trending elongate batholithic body (figure 1B). These rocks often contain bands of enclaves of amphibolites. The megacrysts of feldspar as well as enclaves are usually oriented parallel to the gneissic trend of the country rock (figure 2I) but in some cases, the megacrysts locally show haphazard orientation indicating turbulent flow in magma. The general trend of magmatic foliation is ENE-WSW. The dip ranges from $70^{\circ}$ to $72^{\circ} \mathrm{N}$. In places, the granitoid rocks show $\mathrm{D}_{2}$ folds (figure 2J). Hence, the pluton emplaced before the $\mathrm{D}_{2}$-deformation episode. The strong preferred orientation of the minerals reflects the shearing effect during the $\mathrm{D}_{3}$-deformation (figure $2 \mathrm{~K}$ ).

The long axis of the Agarpur pluton is $\mathrm{E}-\mathrm{W}$ (figure 1B). The rock shows impersistent $\mathrm{E}-\mathrm{W}$ trending and steep dipping magmatic flow foliation (figure 2L). The southern boundary of the pluton is mylonitised by the $\mathrm{D}_{3}$-deformation. The magmatic flow foliation and mylonitic foliation are parallel to the gneissosity of the country rock gneisses. The flattened ribbon-shaped quartz grains parallel to $\mathrm{E}-\mathrm{W}$ foliation defines a megascopic fabric indicative of ductile deformation. Joints develop parallel to this foliation and late mafic magma invaded the rock along these joints (figure $2 \mathrm{M}$ and $\mathrm{N}$ ).

Figure 2. (A) Intrafolial $\mathrm{D}_{1}$ folds in the granitised quartzite, north of Raghunathpur. (B) Overturned $\mathrm{D}_{2}$-antiform in the basic granulites, north of Murlu. Note injection of enderbite along the foliation plane of basic granulite. (C) Shear fold related to $\mathrm{D}_{3}$-deformation in the migmatite east of Jaipur. Note the injection of pink granite along the foliation of the host amphibolite. (D) Injection of enderbite magma in basic granulite at the foothill of Sarpahari. (E) Antiformal $\mathrm{D}_{2}$ fold in enderbite. Note the older enclave of basic granulite is folded with the enderbite arising a false impression of hook-like geometry. (F) A preferred alignment of K-feldspar megacrysts in the porphyritic granite of Raghunathpur. Location: Bero Pahar. (G) Amphibolite xenolith within porphyritic granite of Raghunathpur. Note: swerving of the K-feldspar megacrysts around the xenolith. $(\mathbf{H})$ Augen-shaped megacrysts of K-feldspar at the northern margin of the Raghunathpur granite, near Bero. (I) Parallel alignment of older amphibolite enclave within the Sindurpur pluton. Note the parallelism of the long dimension of amphibolite and foliation of the host granite. (J) $\mathrm{D}_{2}$ folds within the porphyritic granite of Sindurpur. (K) Effect of shearing on the megacrysts of the Sindurpur pluton. Note: stretching of the megacryst. (L) Banding defined by the alternate layers of ferromagnesian and quartzo-feldspathic minerals in the Agarpur pluton. (M) Injection of basic material along the joint planes of the Agarpur pluton. These joints are parallel to the shear planes. (N) A close view of the previous exposure $(\mathbf{M})$. 

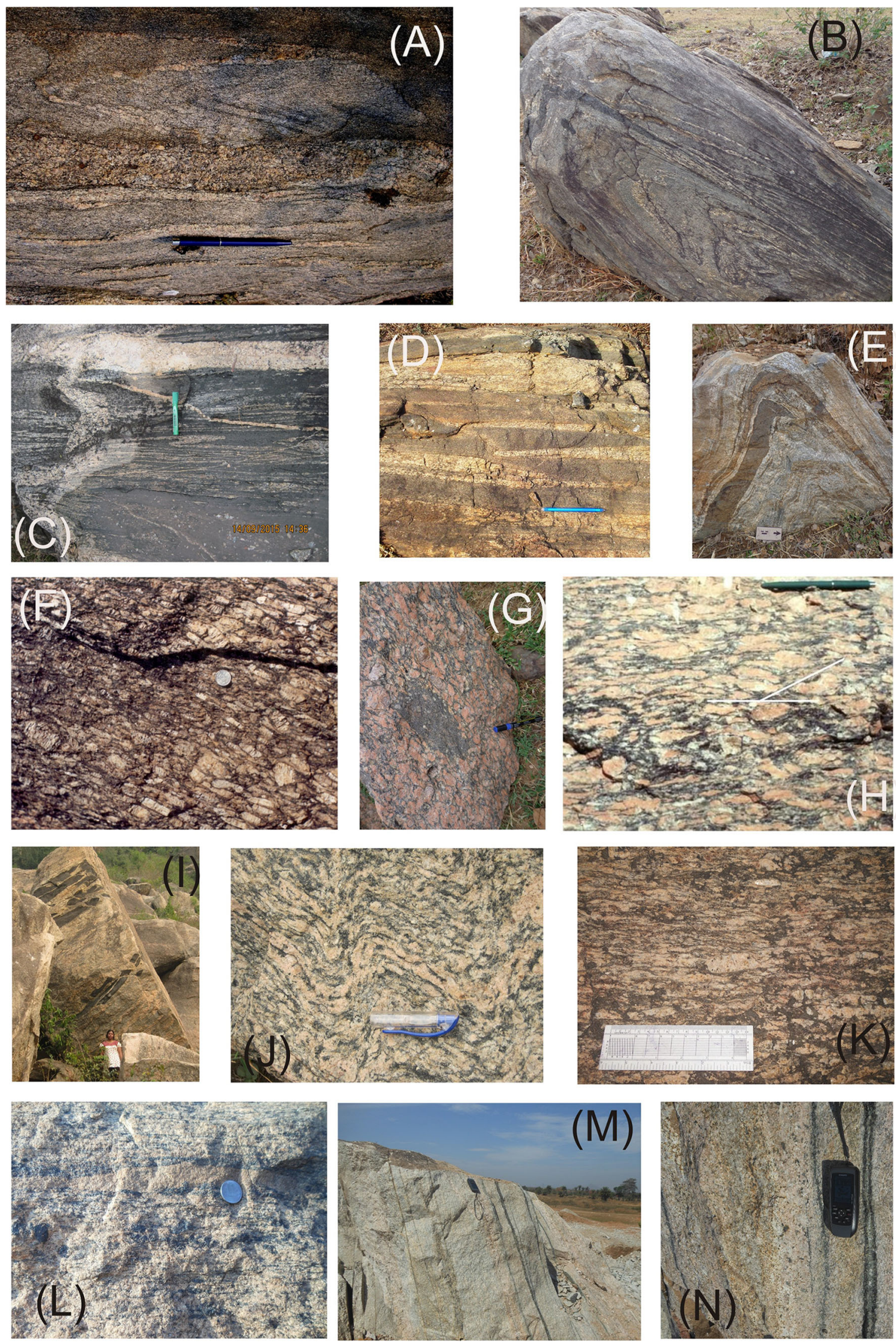


\section{Analytical methods}

Electron probe micro analyses (EPMA) of the representative minerals of these samples were performed using a CAMECA SX100 microprobe with wavelength dispersive spectrometers at the Central Petrology Division, Geological Survey of India, Kolkata. An accelerating voltage of $15 \mathrm{kV}$ was maintained with a beam current of $12 \mathrm{nA}$ and $1 \mu \mathrm{m}$ beam diameter.

The EPMA of the representative minerals of three samples of the Agarpur pluton was performed in a CAMECA SXFive instrument at DST-SERB National Facility, Department of Geology (Centre for Advanced Study), Institute of Science, Banaras Hindu University. An accelerating voltage of $15 \mathrm{kV}$ was maintained with a beam current of $10 \mathrm{nA}$ and $1 \mu \mathrm{m}$ beam diameter. Natural and synthetic standards supplied by CAMECA-AMETEK were used for precision and correction.

The EPMA of the representative minerals from two samples of porphyritic granitoids of the Raghunathpur pluton was performed using a JEOL JXA-8600M microprobe with wavelength dispersive spectrometer at the IIC (Institute Instrumentation Centre), Indian Institute of Technology, Roorkee. An accelerating voltage of $15 \mathrm{kV}$ was maintained with a beam current of $50 \mathrm{nA}$. Beam diameter was fixed at $3 \mu \mathrm{m}$. Natural standards supplied by SPI Suppliers, Structure Probe Inc., Canada, were used for precision and correction.

The precision of data of major elements for all the three instruments is $\pm 3 \%$.

\section{Petrography}

\subsection{Agarpur pluton}

The pluton is medium to coarse grained, grey to brownish colour in outcrop and shows welldeveloped magmatic flow foliation. The pluton is composed of pink-coloured granite and alkali feldspar granite. The major minerals present in the rock are microcline, quartz, plagioclase and amphibole. The accessory phases are allanite, magnetite and apatite. The magmatic flow foliation in the rock is defined by alternate layers of aggregates of ferromagnesian minerals with thicker bands of quartzo-feldspathic mass. The felsic bands contain phenocrysts of microcline giving rise to porphyritic texture (figure 3B). The ferromagnesian bands are composed mainly of a cluster of aggregates of prismatic and lensoidal grains of amphibole.
Intergrowth of quartz with microcline is not uncommon. Subidiomorphic to xenomorphic plagioclases (albite to oligoclase) mainly occur in the groundmass. Myrmekitic intergrowth is not uncommon. The actinolite (pleochroic from light green to bluish green) and subordinate hornblende grains are coarse to medium grained, elongated, irregular and ellipsoidal with subidiomorphic to xenomorphic grain boundary. Allanite (idiomorphic to subidiomorphic) occurs as a cluster of laths and patches in the ferromagnesian bands. Sphenes (pleochroic from light brown to dark brown; subidiomorphic to xenomorphic) are fine to medium grained, elongated parallel to the fabric. Magnetites are idiomorphic, squarish and equant and occur as the inclusion within biotite and amphibole grains. Apatite (idiomorphic to subidiomorphic, hexagonal to rounded, ellipsoidal to prismatic) occurs as a discrete phase within groundmass and also as inclusions within both felsic and mafic minerals.

In the mylonitised zones, impersistent, extremely thin ribbons or elongate streaks of quartz run through the flesh-coloured feldspar parallel to the direction of mylonitic foliation (figure $3 \mathrm{~A}$ ). Phenocrysts of microcline and quartz survived as ellipsoidal or augen-shaped porphyroclast with elongation parallel to the direction of mylonitic foliation.

\subsection{Sindurpur pluton}

The porphyritic granitoids of Sindurpur are composed mainly of K-feldspar, plagioclase, quartz, biotite, hornblende and minor orthopyroxene, opaque, apatite, muscovite, sphene, garnet, allanite and zircon and show distinct banding (figure 3C). A preferred alignment of ferromagnesian (biotite and hornblende) and platy feldspars define the magmatic foliation. Quartz occurs commonly as coarse, elongate, lenticular grains, deformed or warped around microcline megacrysts. It occurs also as tiny (medium to fine grained) xenomorphs intimately associated with feldspar and biotiterich groundmass. K-feldspar (microcline) occurs as megacrysts and coarse subhedra along with aggregates of smaller subhedral crystals, embedded in quartz-plagioclase-biotite-rich medium-grained groundmass. Plagioclase (oligoclase) occurs as medium to coarse, tabular, subidiomorphic grains forming aggregates with other groundmass minerals, mainly quartz, biotite, and occasionally hornblende. Alteration of plagioclase is common. 

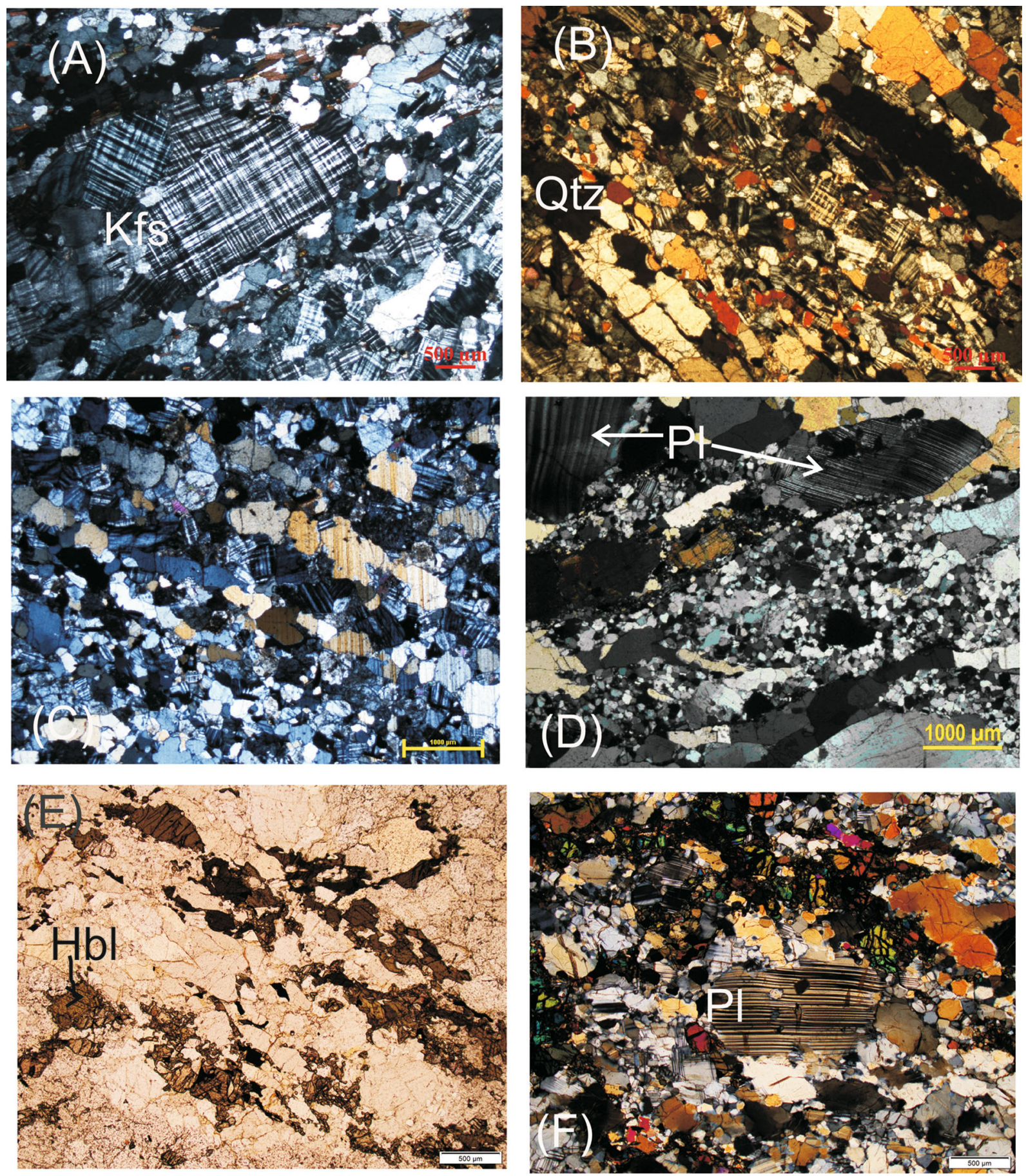

Figure 3. (A) Fine ribbon-shaped quartz within the pink granite. (B) Feldspar megacrysts in the felsic bands of pink granite. (C) Banding defined by the preferred alignment of felsic minerals in the Sindurpur granite. (D) Deformation of plagioclase megacrysts and formation of a finer groundmass in the porphyritic granite of Raghunathpur. (E) Strong dimensional orientation shown by the quartzo-feldspathic minerals and lenses of ferromagnesian minerals in enderbite of Sarpahari. (F) Relict megacryst of plagioclase within a granulated groundmass.

Medium-sized laths and flakes of biotite form clusters in the groundmass and oriented subparallel to foliation. It is intimately associated with hornblende and replaces the latter. Hornblende occurs as xenomorphic to subidiomorphic medium to coarse grains. Orthopyroxene (colourless to light green) and clinopyroxene may be present as relict patch within hornblende. Magnetite, limonite, apatite and sphene occur as accessories. Allanite, zircon, sphene and garnet, when present, occur in trace amounts as subidiomorphic to idiomorphic grains. 


\subsection{Raghunathpur pluton}

The porphyritic granitoids are composed mainly of K-feldspar, plagioclase, quartz, biotite, hornblende and accessory opaque, apatite, chlorite, epidote, allanite, muscovite, sphene, carbonate, garnet, scapolite and zircon in variable proportions. Although most of the porphyritic granitoids lie in the granite and quartz monzonite fields of QAP (Quartz-Alkali feldspar-Plagioclase) diagram (after Streckeisen 1976), few samples lie in the tonalite, granodiorite and alkali feldspar granite fields.

Quartz occurs commonly as coarse, elongate, lenticular grains, deformed or warped around microcline megacrysts. Abundant tabular or (rarely) ellipsoidal megacrysts (1-10 cm long) of $\mathrm{K}$-feldspar occur in quartz-plagioclase-biotite-rich medium-grained groundmass, often bordered by a narrow rim of very-fine-grained anhedral quartz, microcline, sericitised and turbid plagioclase and lobate myrmekite. Ellipsoid megacrysts have 'tails' of millimetre-sized anhedral quartz, plagioclase and microcline which pinch out into more mafic matrix several millimetres from both ends of the megacryst. Medium to coarse, tabular, subidiomorphic plagioclase $\left(\mathrm{An}_{25-40}\right)$ forms aggregate with other groundmass minerals. Plagioclase phenocrysts may show bending of twin lamellae (figure 3D). Biotite occurs as medium-sized laths and flakes forming clusters in the groundmass and oriented subparallel to foliation. It may replace hornblende. Hornblende occurs as xenomorphic to subidiomorphic medium to coarse grains. In some samples, hornblende appears to be replaced by scapolite $\left(\mathrm{Ma}_{72} \mathrm{Me}_{28}\right)$ xenomorphs. Metamict prisms of allanite are often rimmed by epidote. Muscovite, when present, occurs both as subidiomorphic tiny laths and xenomorphic ragged grains secondary after biotite and plagioclase. Zircon and garnet, when present, occur in trace amount as subidiomorphic to idiomorphic grains.

\subsection{Sarpahari pluton}

The main rock type of the Sarpahari pluton is enderbite (opx-tonalite) and charnoenderbite (opxgranodiorite). However, thin bands of enderbite are seen injected along the $\mathrm{S}_{1}$-foliation of the garnetiferous gneisses and basic granulite country rock (figure 2D). Enderbite in the area is a coarsegrained foliated rock, composed of plagioclase, quartz, biotite, hornblende, minor orthopyroxene and accessory opaque, zircon and apatite. The foliation is defined by alternate thicker layers of quartzofeldspathic aggregates with thin impersistant stringers and layers of ferromagnesian minerals through the quartzofeldspathic groundmass. Both quartz and feldspar show strong dimensional orientation and the impersistant layers and lenses of ferromagnesian minerals are oriented parallel to the foliation (figure $3 \mathrm{E}$ ). Coarse plagioclase and quartz grains show protoclastic granulation formed by shearing. Such a medium- to fine-sized granulated mass occurs in the interspaces of coarser quartz and feldspar. Plagioclase occurs as coarse, equant to elongated, xenomorphic to subidiomorphic grains as well as aggregates of fine-sized subidiomorphic equant grains. Coarser plagioclase generally shows the deformation effect in the form of bending of twin lamellae and also shadowy extinction (figure 3F). Quartz occurs as coarse, equant to elongated, xenomorphic to subidiomorphic grains as well as aggregates of fine-sized subidiomorphic equant grains. Some of the quartz grains are lenticular and such lenticles are more strongly oriented parallel to foliation. Biotite (pleochroic from straw yellow to reddish brown) occurs commonly as medium-sized laths. Biotites may replace orthopyroxene. Orthopyroxenes (pleochroic from pale pinkish to pale greenish) and clinopyroxenes occur as aggregates of ragged grains running along the foliation. Coarser ragged grains are occasionally marginally crushed. The fine- to medium-sized granules occupy the interspaces of the adjacent felsic grains. Hornblendes occur as an aggregate of subidiomorphic to xenomorphic elongated grains and are closely associated with orthopyroxene. At places, orthopyroxenes are altered to hornblende. Sometimes hornblendes form corona structure around opaque minerals. Opaque minerals occur as both equant and elongated grains intimately associated ferromagnesian minerals. Fine zircon (elongated pyramidal grains) and apatite (equant, subidiomorphic grains) occur as inclusion in feldspar as well as the interspaces.

\section{Nature of fabric in granitoid plutons}

Emplacement of granitic bodies can be considered either linked to orogenic processes (syn-tectonic) or may be rift-related anorogenic (Pitcher 1997). A granitoid pluton involved in regional deformation develops a flow fabric in response to tectonic forces. If the granitoid pluton has been emplaced in the absence of tectonic forces, the magmatic fabric 
reflects the dynamics of emplacement (Hutton 1988; Brown and Solar 1998; Paterson et al. 1998; Rosenberg 2004). The mineral fabric of granite records the strain field of the magma during the final stages of emplacement (Paterson et al. 1998). The fabric defined by the alignment of subhedral to euhedral zoned plagioclase or mafic minerals such as hornblende and biotite is considered as melt present flowage (magmatic flow or submagmatic flow with $<20 \%$ melt; Hutton 1988; Paterson et al. 1989).

All the four plutons were primarily emplaced as magmas in the country rocks under amphibolite facies (Raghunathpur, Agarpur plutons) and granulite facies environment (Sarpahari and Sindurpur plutons) (Goswami and Bhattacharyya 2008).

The intensity of deformation in the interior of all the granitoid bodies of the present study is different from their margin. The central part of the granitoid bodies is massive with the haphazard orientation of megacrysts and show weak imprints of solid-state deformation in the form of local shearing. The border zones of all these granitoid bodies show the development of augen gneisses and mylonites. A detailed study on the origin of the fabric of porphyritic granitoid batholith of Raghunathpur had been published earlier by Goswami and Bhattacharyya (2014).

Typical igneous textures in these granitoids include a porphyritic texture (e.g., Ridley 1992), characterised by idiomorphic to subidiomorphic K-feldspar and plagioclase (e.g., Shelley 1993; Frost et al. 2000), which show preferred orientation. However, anhedral feldspar is present in these granitoids due to impingement (Vernon 2004). Plagioclase shows lamellar twinning typical of igneous rocks (Shelley 1993). Intergrowth of quartz within microcline is a clear evidence of magmatic crystallisation of the Agarpur pluton. Biotitisation of orthopyroxene in enderbite can be taken as an evidence for the presence of a melt phase where biotite-quartz were formed according to the reaction Opx + melt = Bt + Qtz (Kramers and Ridley 1989; Bohlender et al. 1992; Ridley 1992). Elongated, bipyramidal, euhedral zircons in enderbite suggest their igneous origin.

Sheared parts of all of these granioid plutons are marked by porphyroclasts of plagioclase (albiteoligoclase) and microcline in a matrix of undulose quartz and granulated quartz-feldspar. Formation of ribbons of quartz is commonly found in the shear zones. Occasional bending of twin lamellae in plagioclase indicates the limited plastic deformation of feldspar. In the deformed zones of the Agarpur pluton, myrmekite is quite common and occurs in both, weakly deformed granites as well as in granite mylonites. Completely recrystallised quartz ribbons and myrmekite suggest fabric development under intermediate temperature $\left(\sim 500-400^{\circ} \mathrm{C}\right)$.

The broadly E-W elongation of these plutons concurs with the trend of NPSZ which suggests control of this shear zone in framing the orientation of these plutons. The preferred $\mathrm{E}-\mathrm{W}$ orientation of the feldspar megacrysts and ferromagnesian minerals with the exception in some places is considered by us to suggest magmatic flowage differentiation. The prolongation of the shearing movement after solidification of the granitoid magmas accentuated the preferred orientation and granulation of minerals. In such a situation, the textural equilibration is favoured in magmatic rocks if temperatures remain high in the system (Maaløe 1985; Hunter 1987). In the case of the four granitoid plutons of the present study, the chemical compositions of the magmatic minerals have not been altered and hence the physico-chemical parameters derived from the mineral chemistry reveal the original magmatic crystallisation.

\section{Mineral chemistry}

\subsection{Feldspar}

Representative analyses of K-feldspar and plagioclase in the studied plutons are shown in tables 1 and 2 .

In the $\mathrm{Ab}-\mathrm{Or}-\mathrm{An}$ ternary diagram (figure 4, after Deer et al. 1992), plagioclase compositions in the Agarpur pluton range from oligoclase to albite $\left(\mathrm{An}_{26.9}\right.$ and $\left.\mathrm{An}_{9.3}\right)$. The compositional variation of plagioclase in the Sindurpur and Raghunathpur plutons ranges from andesine to albite. For Sindurpur pluton, the compositional variation ranges from $\mathrm{An}_{43.2}$ to $\mathrm{An}_{3.9}$ and for Raghunathpur pluton, it ranges from $\mathrm{An}_{47}$ to $\mathrm{An}_{0.4}$. Such a large variation in Na-content is possibly related to alterations and the albite could be secondary as seen in petrographic observation. The composition of plagioclase in the Sarpahari pluton varies from andesine to oligoclase $\left(\mathrm{An}_{35.6-15.8}\right)$.

Alkali feldspar in the Agarpur pluton corresponds to orthoclase with Or content between $85 \%$ and $100 \%$ (figure 4). These alkali feldspars 


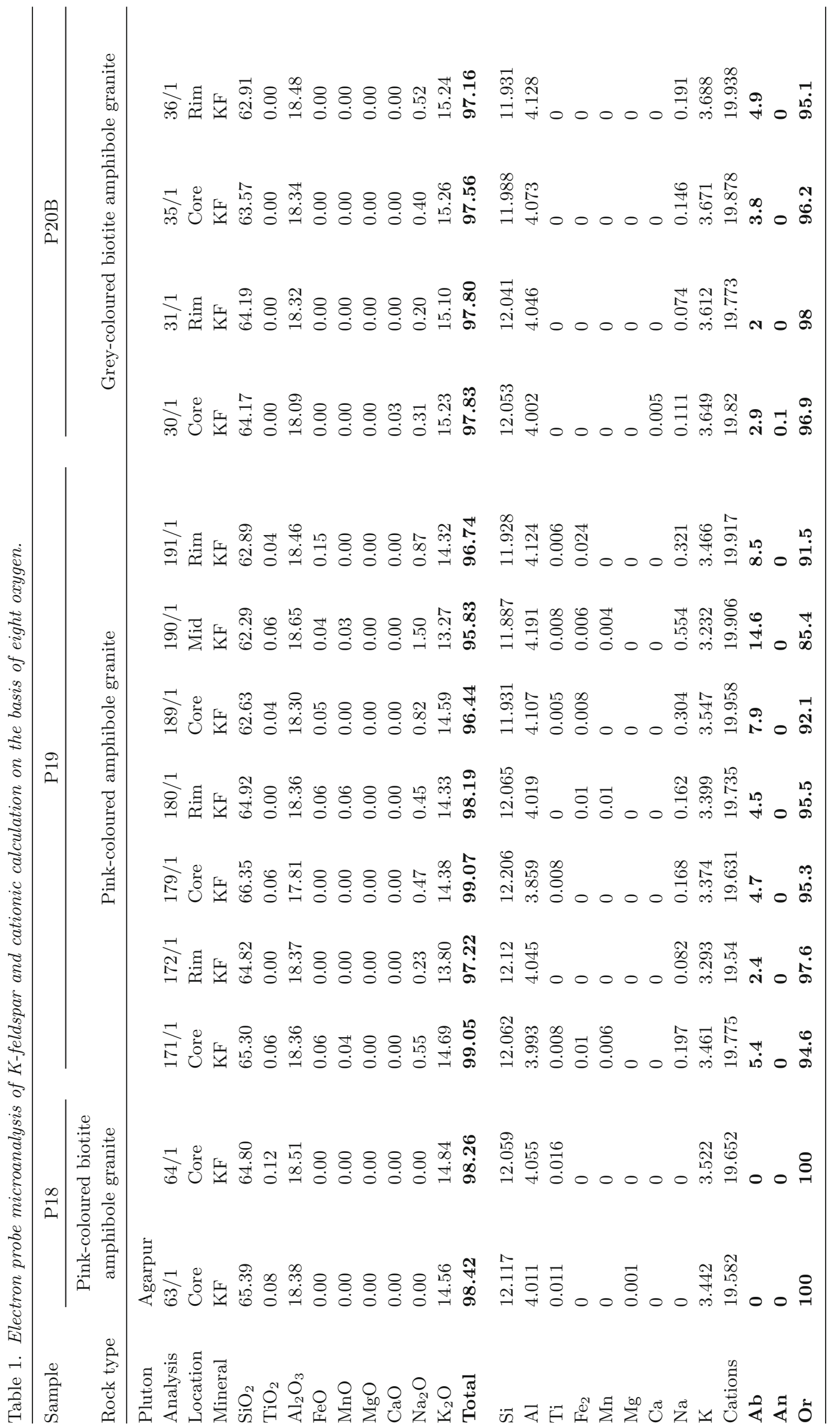




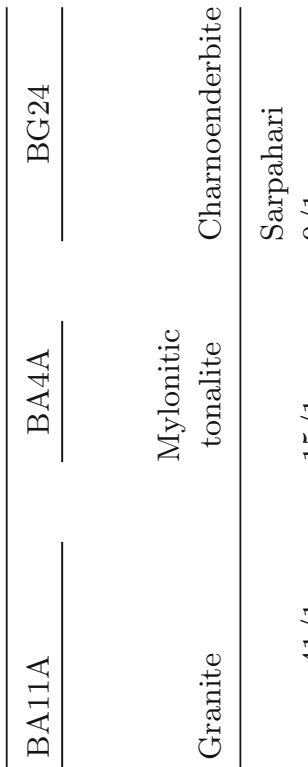

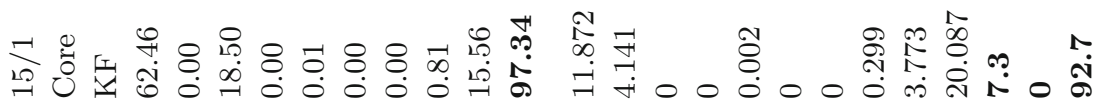

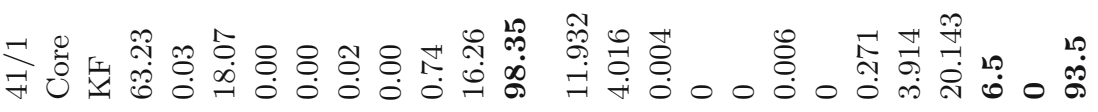

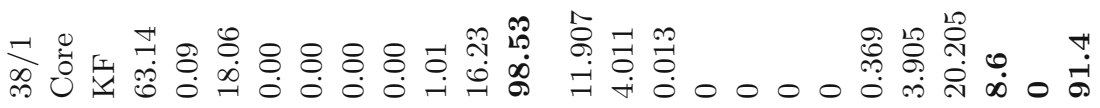

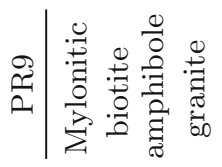

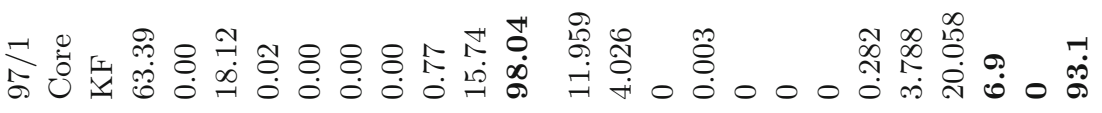

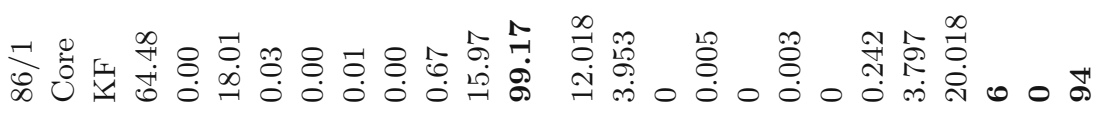

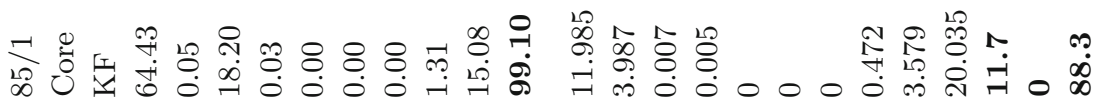

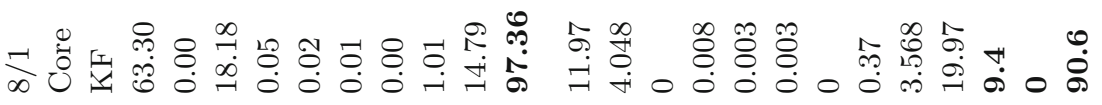

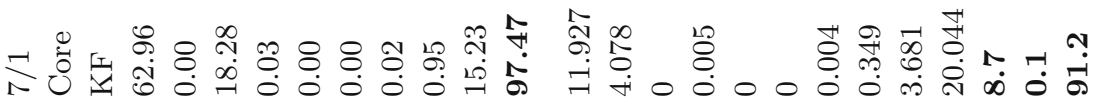
蒙

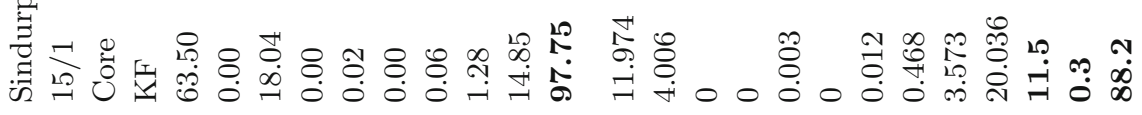

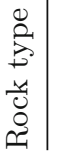

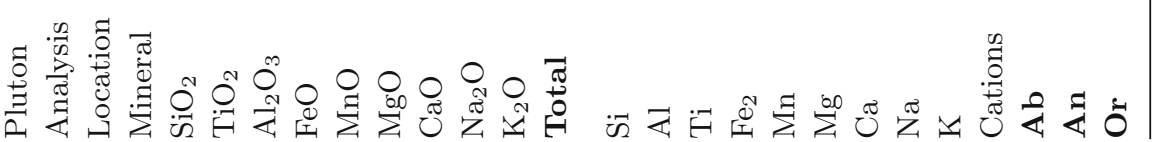




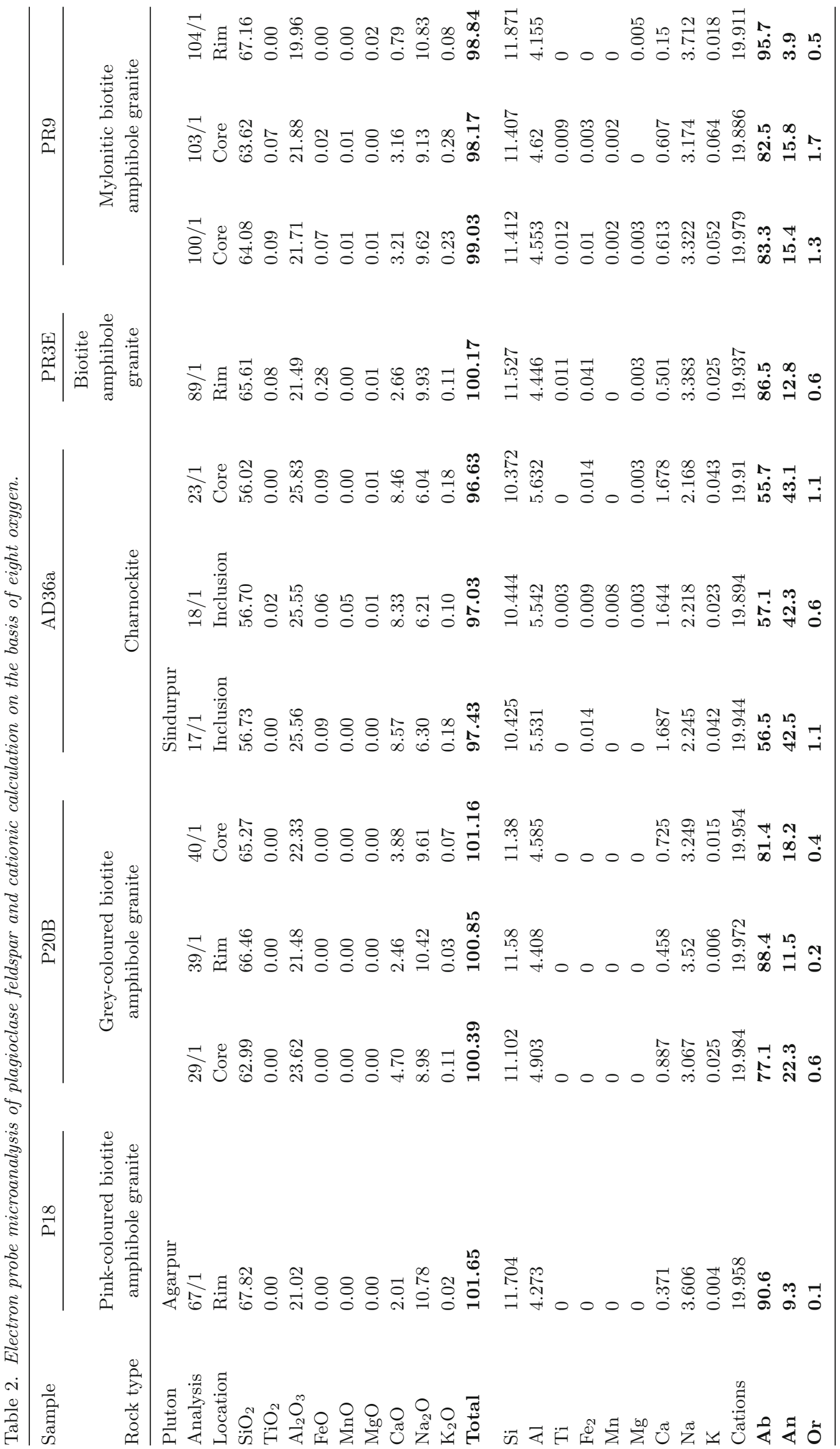




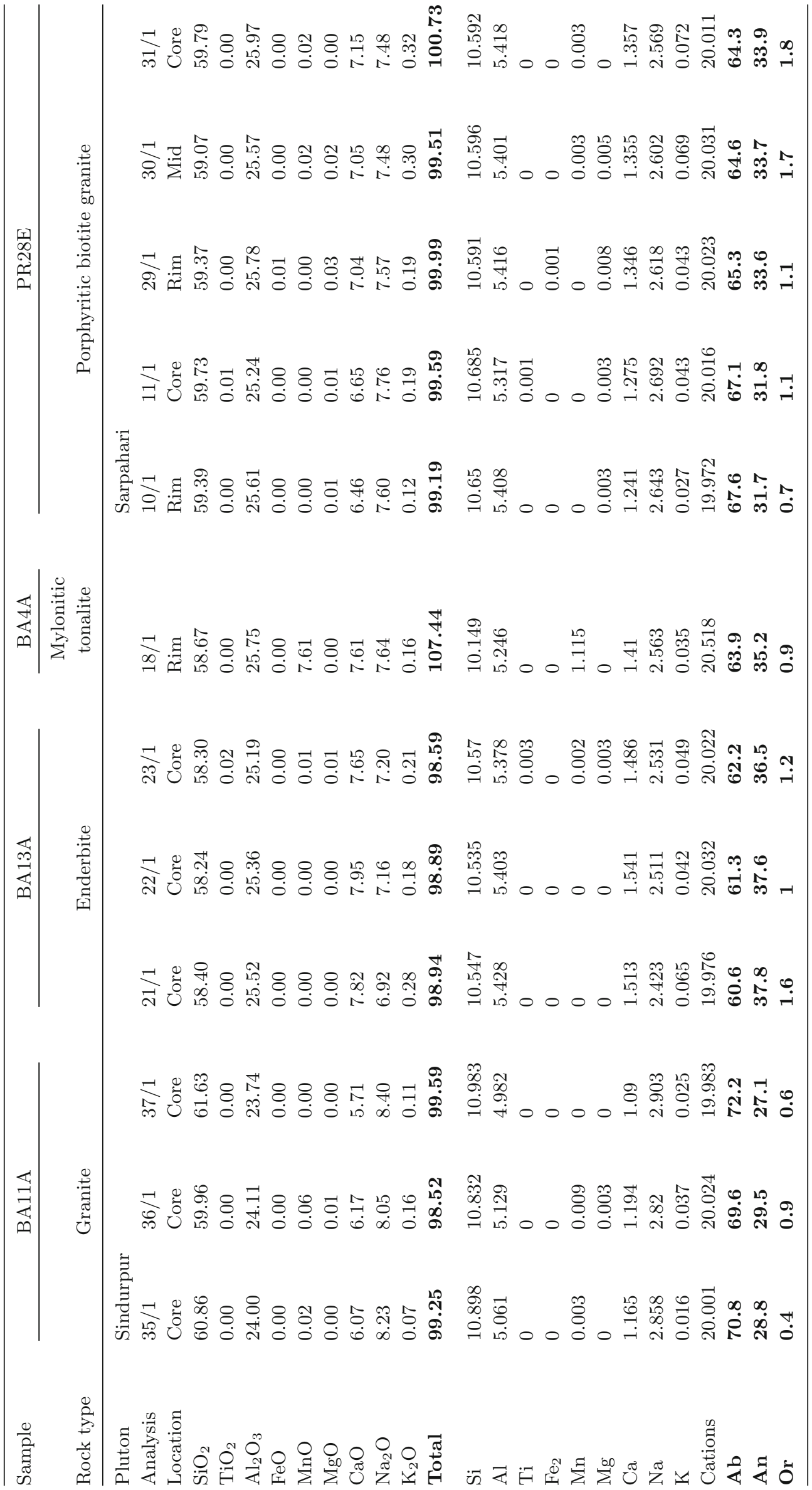




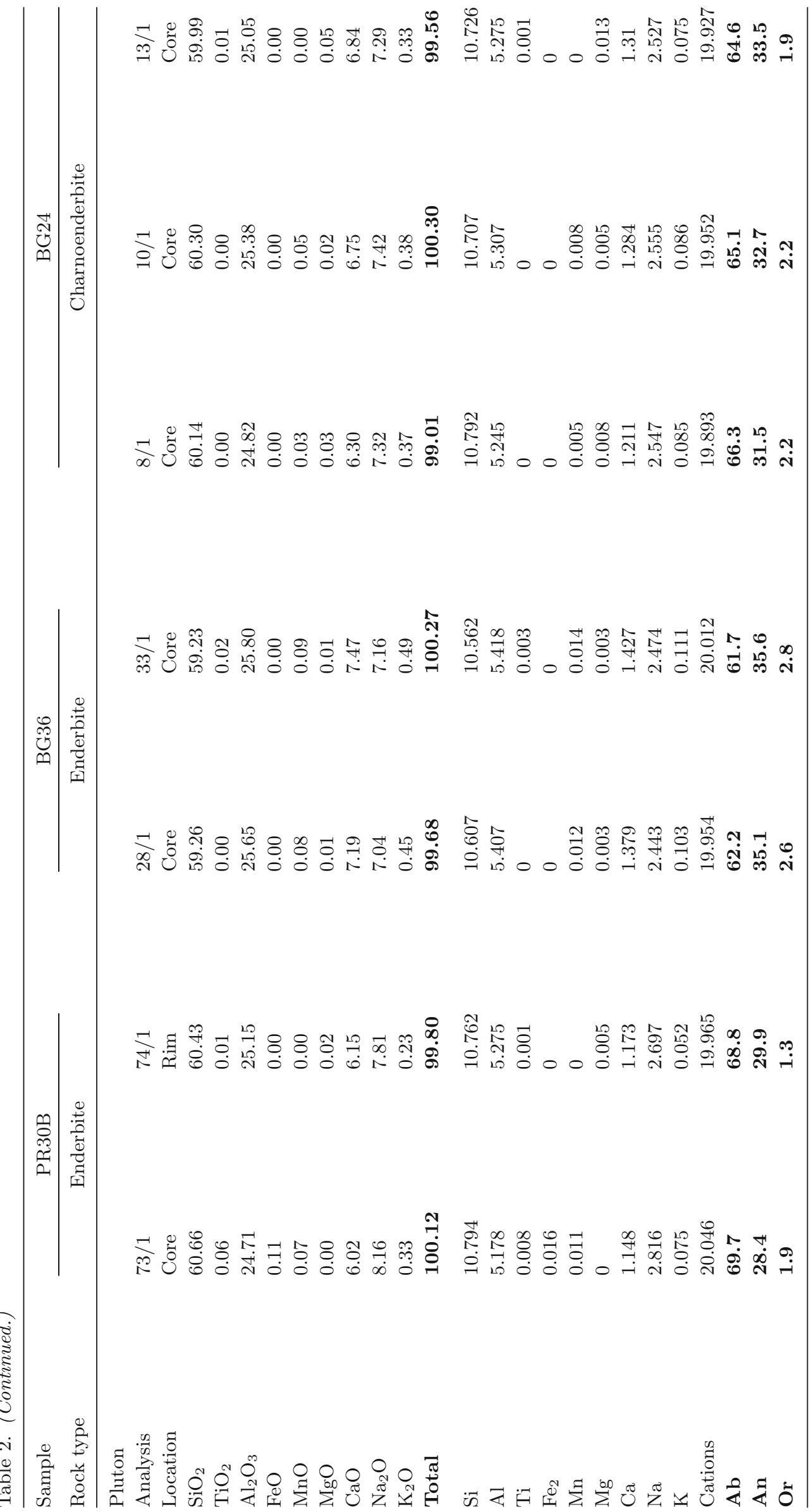




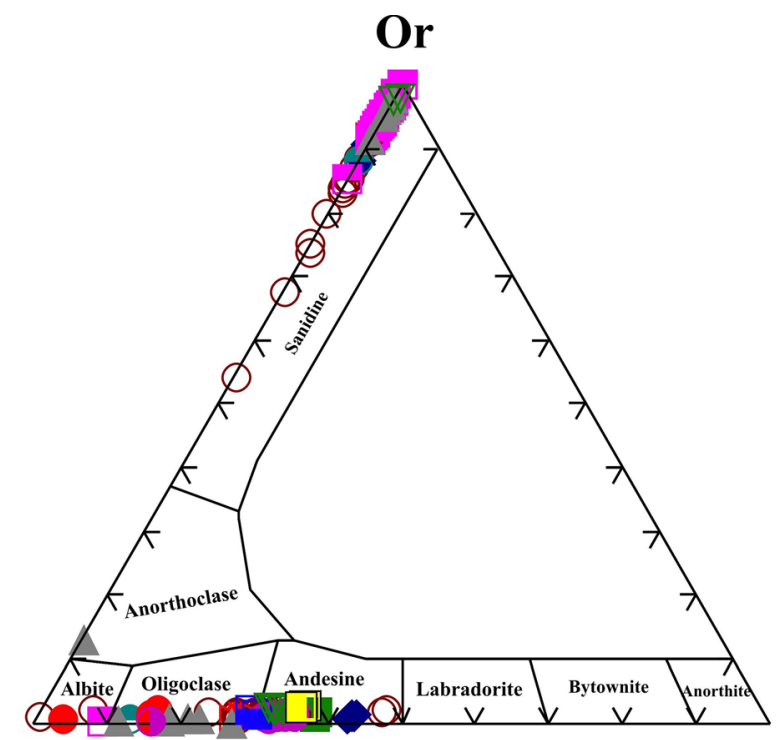

Ab

An

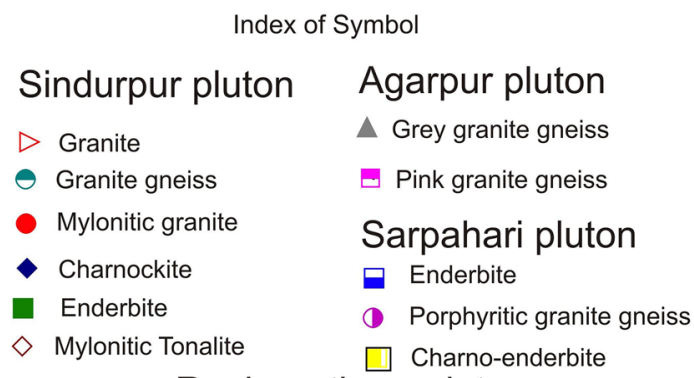

Raghunathpur pluton

Porphyritic granite

Figure 4. Nomenclature of feldspar of granitoids according to Deer et al. (1992) classification scheme. The data source of the Raghunathpur pluton: Goswami and Bhattacharyya (2014).

are totally devoid of anorthite content. Orthoclase component of alkali feldspars of the Sindurpur pluton ranges between $\mathrm{Or}_{94}$ and $\mathrm{Or}_{88.2}$. A small amount of An component (up to $0.5 \mathrm{~mol} \%$ ) may be present in the alkali feldspars of the Sindurpur pluton. In the perthitic alkali feldspar of the Raghunathpur pluton, the compositions of alkali feldspar vary from $\mathrm{Or}_{54.1} \mathrm{Ab}_{45.3}$ to $\mathrm{Or}_{93.5} \mathrm{Ab}_{6.5}$, while albite of composition $\mathrm{Ab}_{95.5} \mathrm{Or}_{0.9}$ exsolved from the alkali feldspar.

Compositional variations of feldspar megacrysts from core to rim also attest to their igneous origin (tables 1 and 2).

\subsection{Biotite}

Representative analyses of biotite of all the four plutons are given in table 3 and their plots are given in figure 5 .
The range of molar $\mathrm{Fe}^{2+} /\left(\mathrm{Fe}^{2+}+\mathrm{Mg}\right)$ of the biotite composition for these plutons is high. The highest variation of biotite composition is encountered in the Sindurpur pluton (0.42-0.95). Biotites of the Agarpur pluton are low in $\mathrm{Al}_{\mathrm{VI}}$ ( p p.f.u.). The Sindurpur pluton shows a bimodal distribution in the composition of biotite. Some biotites are clustered around $\mathrm{Fe} /(\mathrm{Fe}+\mathrm{Mg})$ values 0.5 and other biotites show $\mathrm{Fe} /(\mathrm{Fe}+\mathrm{Mg})$ ratio $\sim 0.95$. Fe $/(\mathrm{Fe}+\mathrm{Mg})$ ratio in the Raghunathpur pluton shows clustering around 0.55. The Sarpahari pluton shows bimodal distribution in respect of $\mathrm{Fe} /(\mathrm{Fe}+\mathrm{Mg})$ ratio. Biotites of enderbite samples of this pluton show $\mathrm{Fe} /(\mathrm{Fe}+\mathrm{Mg})$ ratio around 0.5 , but biotites from granite samples are richer in $\mathrm{Fe}$ and show $\mathrm{Fe} /(\mathrm{Fe}+\mathrm{Mg})$ values around 0.75 .

Nachit et al. (2005) proposed $\mathrm{TiO}_{2}-(\mathrm{FeO}+$ $\mathrm{MnO})-\mathrm{MgO}$ ternary diagram as a quantitative objective tool for distinguishing between primary magmatic biotites and those that are more or less reequilibrated, or neoformed, by or within a hydrothermal fluid. The magmatic origin of biotites of the present study is supported by their chemical composition (figure 6).

\subsection{Amphiboles}

Amphibole is the predominant mafic phase in all these granitoids. Ferrous and ferric iron in the amphibole formula was calculated using the charge balance method. Structural formulae of amphiboles were calculated on an anhydrous basis assuming $23 \mathrm{O}$ atoms per half unit cell, with the general form $\mathrm{A}_{0-1} \mathrm{~B}_{2} \mathrm{C}_{5} \mathrm{~T}_{8} \mathrm{O}_{22}(\mathrm{OH})_{2}$ representing 1 formula unit. According to the IMA classification and $\mathrm{Fe}^{3+}$ calculation proposed by Leake et al. (1997), all the amphiboles are classified as calcic amphiboles $\left[\sum(\mathrm{Ca}+\mathrm{Na})\right.$ on $\mathrm{M} 4 \geq 1.00$ with $\mathrm{Na}<0.5$ and $\mathrm{Ca} \geq 1.5$ on M4]. In the classification scheme, the calcic amphiboles are further classified into four groups:

(a) $\left.(\mathrm{Na}+\mathrm{K})^{\mathrm{A}} \geq 0\right) 50$ and $\left.\mathrm{Ti}<0\right) 50$;

(b) $(\mathrm{Na}+\mathrm{K})^{\mathrm{A}} \geq 0$ : 50 and $\left.\mathrm{Ti} \geq 0\right) 50$;

(c) $\left.(\mathrm{Na}+\mathrm{K})^{\mathrm{A}}<0\right) 50$ and $\left.\mathrm{Ca}^{\mathrm{A}}<0\right) 50$;

(d) $(\mathrm{Na}+\mathrm{K})^{\mathrm{A}}<0.50$ and $\mathrm{Ca}^{\mathrm{A}} \geq 0.50$.

Representative compositions of amphiboles from different plutons are given in table 4 .

Amphiboles of the Agarpur pluton can be classified into two groups; however, both of these groups may occur in the same rock. Group (a) amphiboles, characterised by $(\mathrm{Na}+\mathrm{K})^{\mathrm{A}}<0.5$ and 


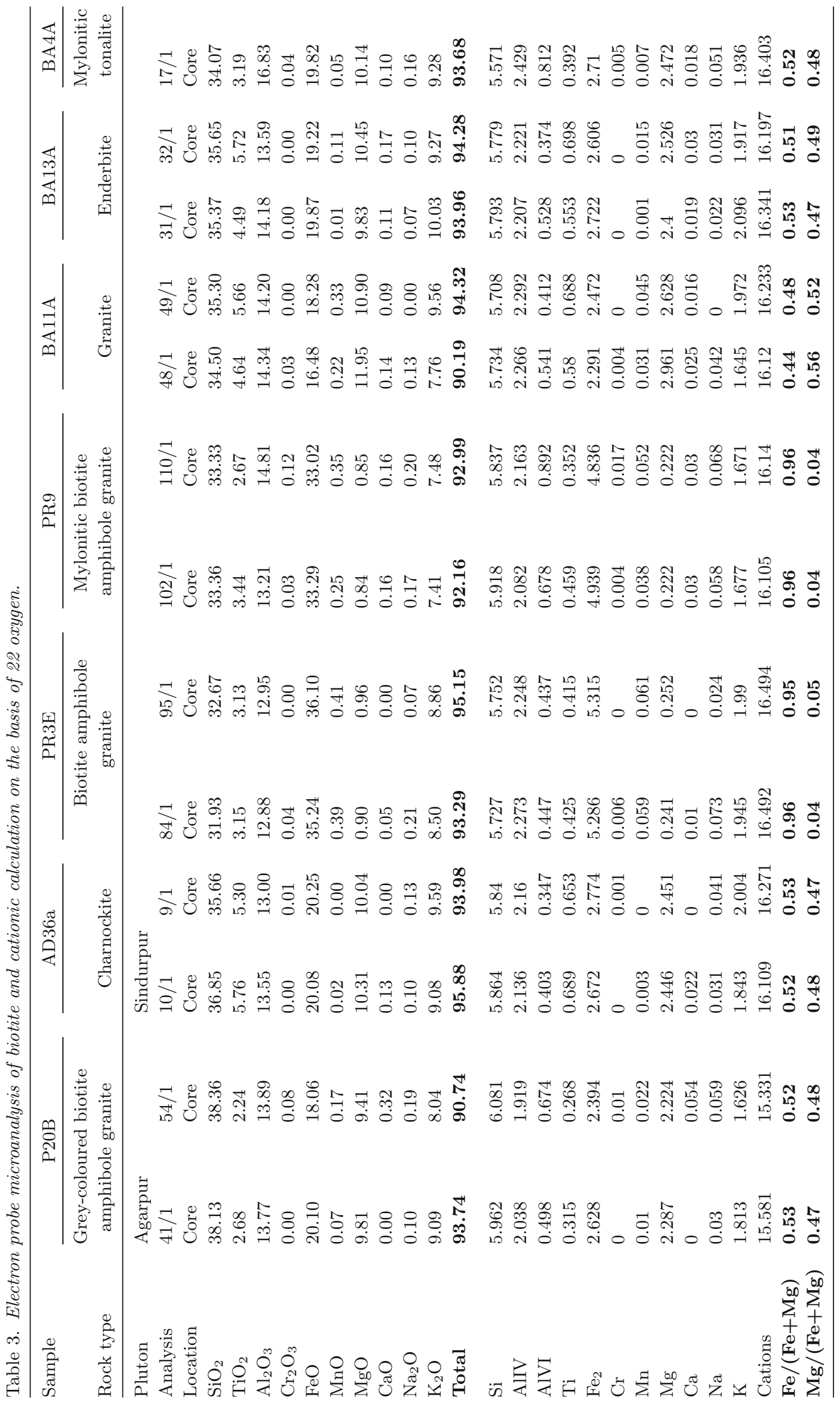




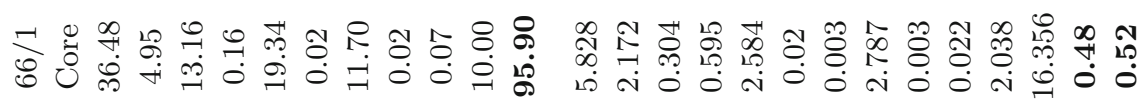

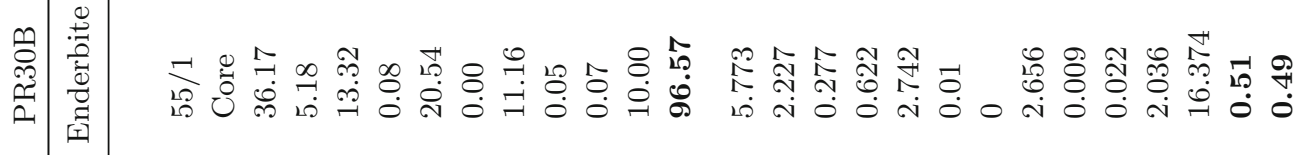

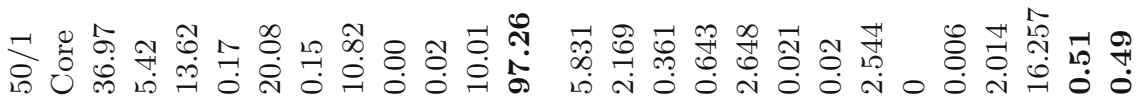

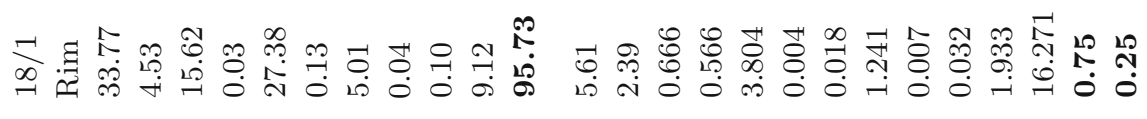

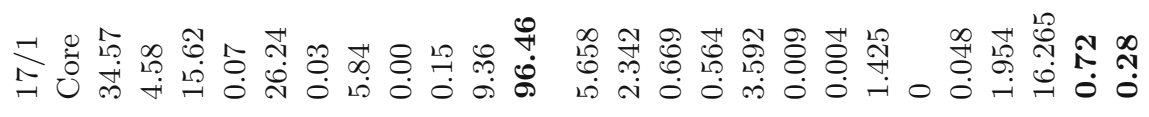

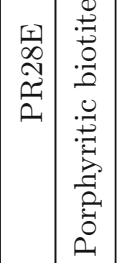

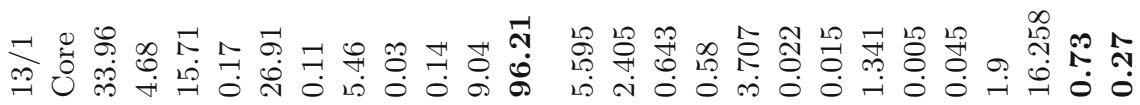

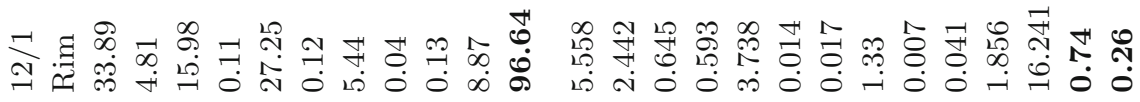

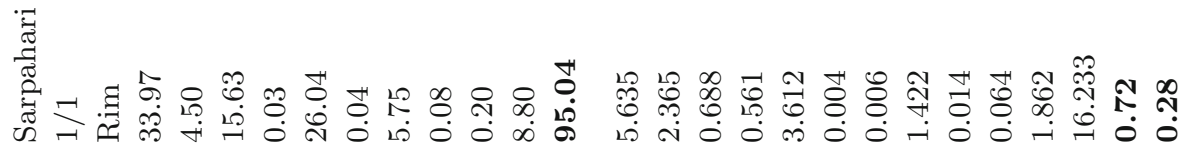




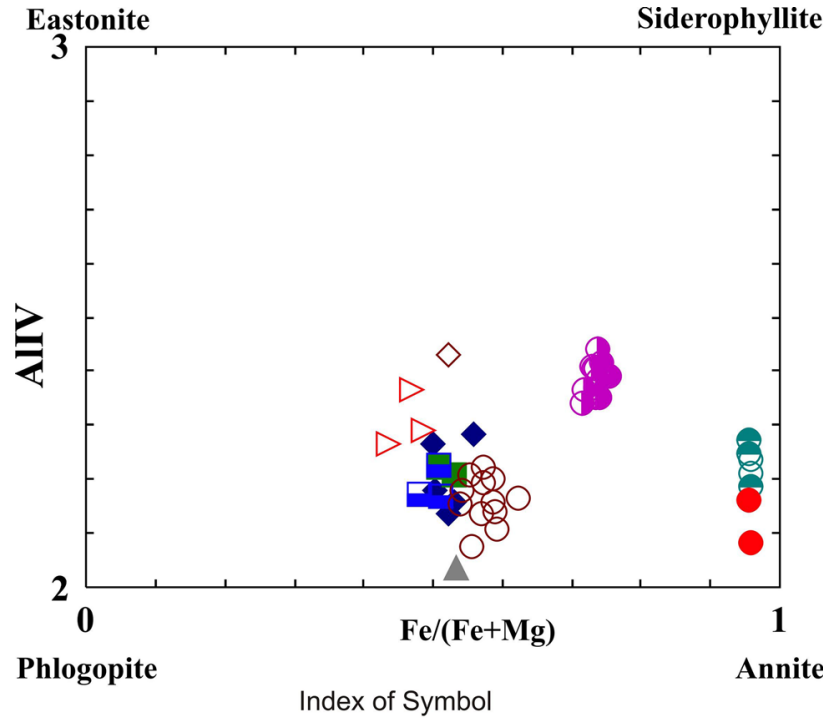

Sindurpur pluton

$\triangleright$ Granite

$\ominus$ Granite gneiss

- Mylonitic granite

- Charnockite

Enderbite

$\diamond$ Mylonitic Tonalite
Agarpur pluton

$\Delta$ Grey granite gneiss

Sarpahari pluton

Enderbite

- Porphyritic granite gneiss

Raghunathpur pluton

Porphyritic granite

Figure 5. Classification of biotite of granitoids according to Deer et al. (1992). The data source of the Raghunathpur pluton: Goswami and Bhattacharyya (2014).

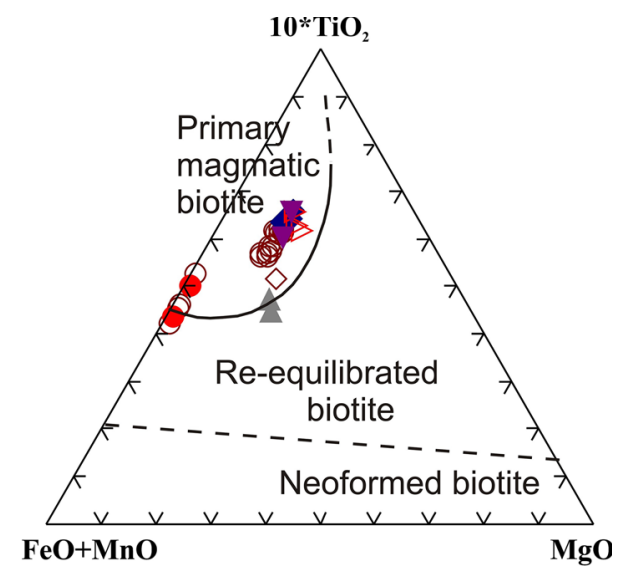

Figure 6. The composition of biotites in the $10 \mathrm{TiO}_{2}-$ $\mathrm{FeO}^{*}-\mathrm{MgO}$ ternary diagram (Nachit et al. 2005 ). $\mathrm{FeO}^{*}=$ $\left[\mathrm{FeO}+\left(0.89981 * \mathrm{Fe}_{2} \mathrm{O}_{3}\right)\right]$. Symbols are same as those of figures 3 and 4 . The data source of the Raghunathpur pluton: Goswami and Bhattacharyya (2014).

$\mathrm{Ti}<0.5$ apfu (atoms per formula unit) are dominant among the pink granite and magnesiohornblende is the dominant species of the granite with subordinate actinolitic hornblende.

All the amphiboles of the Raghunathpur pluton belong to Group (a) with $(\mathrm{Na}+\mathrm{K})^{\mathrm{A}}>0.5$,

$\mathrm{Ti}<0.5$. Magnesian hastingsite is the most common amphibole of this pluton, followed by magnesian hastingsitic hornblende.

Amphiboles of the Sindurpur pluton belong to all four groups. While amphiboles of the granite and charnockite of the Sindurpur pluton are classified as hastingsite and magnesian hastingsite, amphiboles of enderbites belong to edenite species.

Group (c) amphiboles occur more rarely and are defined by $(\mathrm{Na}+\mathrm{K})^{\mathrm{A}}<0.5$ with ${ }^{\mathrm{T}} \mathrm{Si}<6.5$ apfu, and are classified as tschermakite. Tschermakite rarely occurs in charnockite.

Amphiboles of Sarpahari enderbites belong to two groups. Group (a) amphiboles are common and are defined by $(\mathrm{Na}+\mathrm{K})^{\mathrm{A}}>0.5$ with low ${ }^{\mathrm{T}} \mathrm{Si}<6.5 \mathrm{apfu}$ and are classified as magnesian hastingsite and magnesian hastingsitic hornblende or pargasitic hornblende.

Compositions of amphiboles are plotted in the $\mathrm{Si}$ vs. $\mathrm{Ca}+\mathrm{Na}+\mathrm{K}$ diagram of Leake (1971) in which most of the analyses plot well within the field of igneous amphibole while a few analyses from pink granite of Agarpur cross the boundary of the igneous field and enters into the metamorphic field (figure 7).

\subsection{Pyroxene}

Electron microprobe analyses of representative clino- and orthopyroxenes are shown in tables 5 and 6, respectively. All of the pyroxenes in this area are Na-poor and their composition falls in the quadrilateral pyroxene field according to the Morimoto's (1988) nomenclature (figure 8). Both clinoand orthopyroxenes are present in the Sindurpur pluton. While clinopyroxene is diopside $\left(\operatorname{En}_{34.21}\right.$ $\mathrm{Fs}_{19.2} \mathrm{Wo}_{44.5}$ to $\mathrm{En}_{34.3} \mathrm{Fs}_{16.2} \mathrm{Wo}_{47.2}$ ), the orthopyroxene of the Sindurpur pluton is hypersthene $\left(\mathrm{En}_{52.5} \mathrm{Fs}_{48.8}-\mathrm{En}_{50.1} \mathrm{Fs}_{46.2}\right)$ (figure 8). Both clinoand orthopyroxenes are present in the Sarpahari pluton. Clinopyroxene of the Sarpahari pluton is diopsidic $\left(\mathrm{En}_{34} \mathrm{Fs}_{17.5} \mathrm{Wo}_{45.7}\right.$ to $\left.\mathrm{En}_{30.7} \mathrm{Fs}_{20.8} \mathrm{Wo}_{46.2}\right)$ and orthopyroxene composition in this pluton varies from $\mathrm{En}_{60.2} \mathrm{Fs}_{49} \mathrm{Wo}_{1.2}$ to $\mathrm{En}_{48.7} \mathrm{Fs}_{39.0} \mathrm{Wo}_{0.0}$ (figure 8).

\section{Physico-chemical parameters of magmas}

\subsection{Pressure estimates}

Al-in-hornblende barometry has been widely used to calculate pressures of magmatic crystallisation 


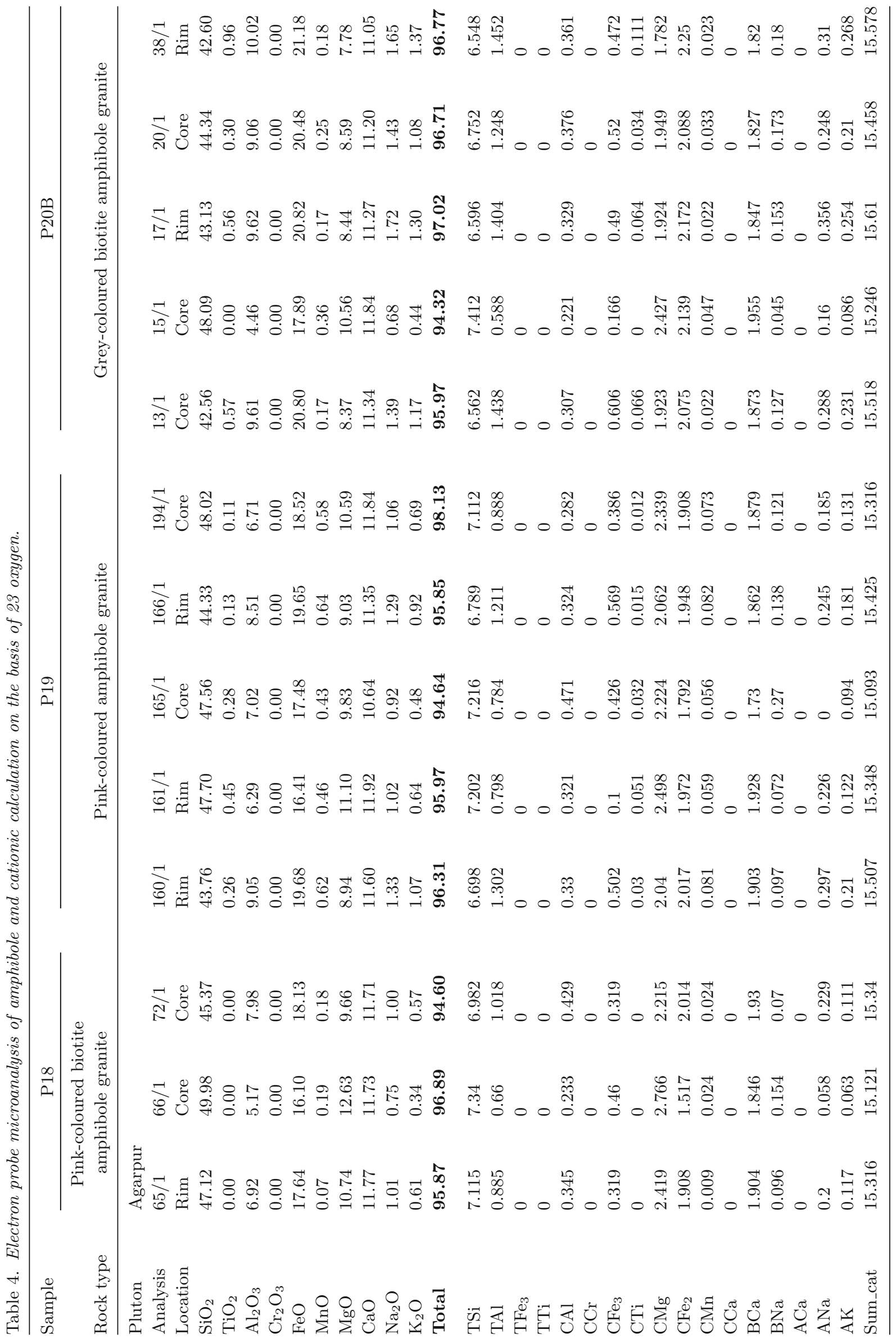




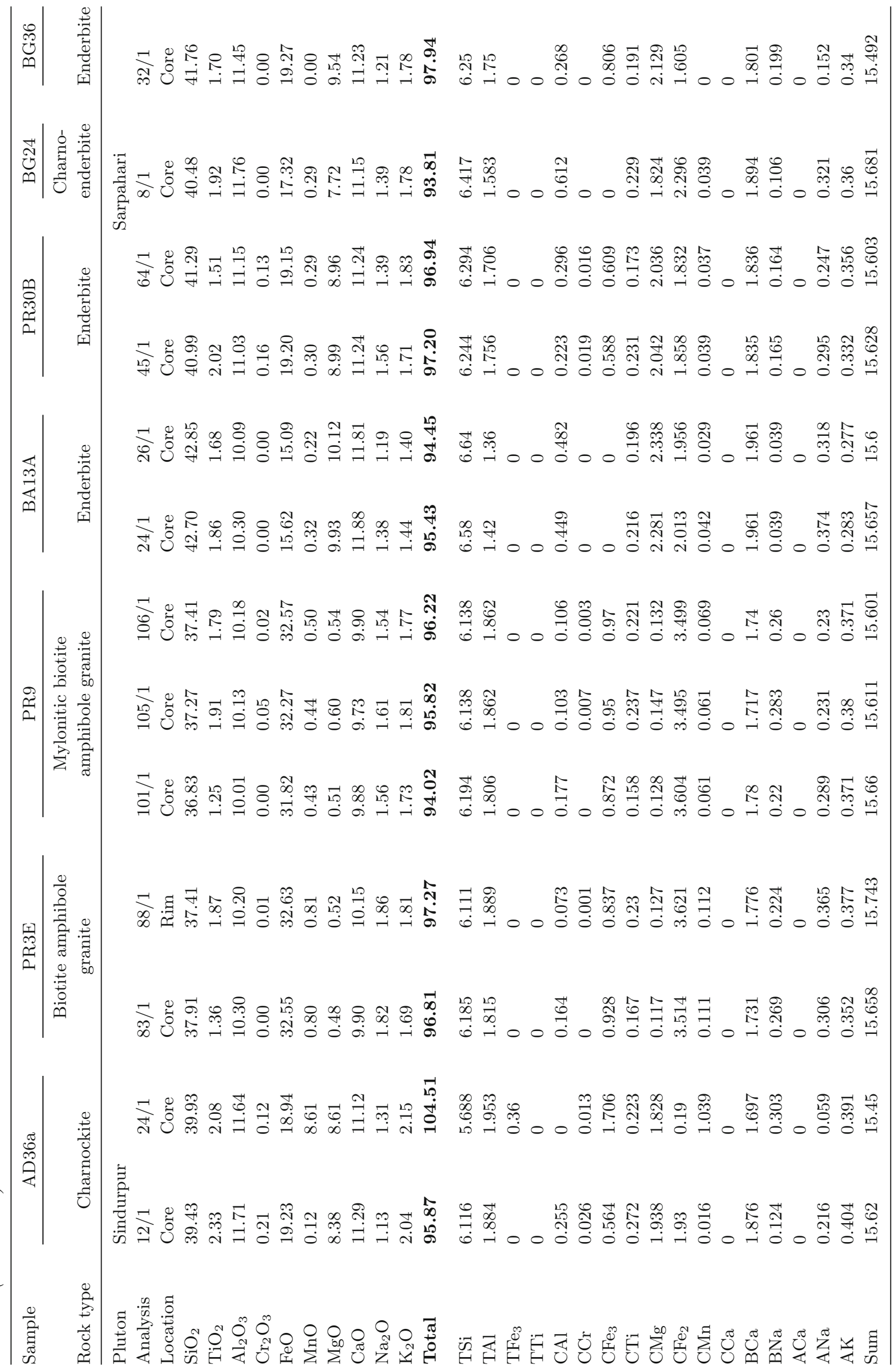




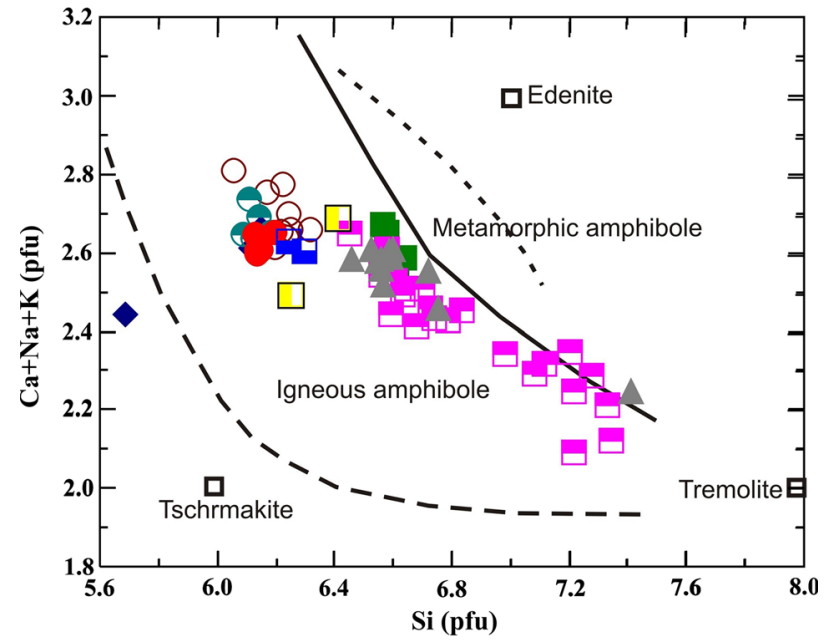

Figure 7. The plot of amphibole composition in the $\mathrm{Si} v s$. $\mathrm{Ca}+\mathrm{Na}+\mathrm{K}$ discriminating diagram separating the fields of igneous and metamorphic amohiboles (Leake 1971 in Deer et al. 1997). Note: most of the amphiboles of the present study plot within the field of igneous amphibole. Symbols are the same as those of figures 3 and 4 . The data source of the Raghunathpur pluton: Goswami and Bhattacharyya (2014).

of calc-alkaline granitoids and to constrain the emplacement depths of batholiths. This barometry can be used only when the suitable mineral assemblages, i.e., quartz + plagioclase + alkali feldspar + biotite + hornblende + titanite + magnetite or ilmenite are present in the granitic rocks (e.g., Vyhnal et al. 1991; Anderson and Smith 1995). In this paper, all the selected samples have the above mineral assemblage. According to Anderson and Smith (1995), this barometry is applicable to hornblendes which have crystallised at approximately the same temperature close to the isothermal solidus and they recommended measurement of rim composition for this study. Moreover, this barometry is applicable for those hornblendes only which occur in contact with quartz and K-feldspar (Stein and Dietl 2001). For each sample, rim composition of co-existing hornblende and plagioclase was measured. In all cases, hornblende is in contact with quartz and K-feldspar.

Oxygen fugacity plays an important role in the Al substitution in hornblende. Oxygen fugacity controls the $\mathrm{Mg} \#\{=\mathrm{Mg} /(\mathrm{Mg}+\mathrm{Fe})\}$ and $\mathrm{Fe}^{3+} /\left(\mathrm{Fe}^{2+}+\mathrm{Fe}^{3+}\right)$ ratios in the magma. Anderson and Smith (1995) estimated that $\mathrm{Mg} \#$ of hornblende in the range from 0.4 to $1,0.2$ and 0.4 and 0.4 to 0 indicates, respectively, the high, medium and low oxygen fugacity. A high oxygen fugacity favours incorporation of $\mathrm{Fe}^{3+}$ and substitutes $\mathrm{Al}$ in hornblende lattice. So Al-content of
Table 5. Electron probe microanalysis of clinopyroxene and cationic calculation on the basis of six oxygen.

\begin{tabular}{|c|c|c|c|c|}
\hline \multirow{3}{*}{$\begin{array}{l}\text { Sample } \\
\text { Rock type } \\
\text { Pluton }\end{array}$} & \multicolumn{2}{|c|}{ BA13A } & \multicolumn{2}{|c|}{ BG24 } \\
\hline & \multicolumn{2}{|c|}{ Enderbite } & \multicolumn{2}{|c|}{ Charnoenderbite } \\
\hline & \multicolumn{2}{|c|}{ Sindurpur } & \multicolumn{2}{|c|}{ Sarpahari } \\
\hline Analysis & $28 / 1$ & $29 / 1$ & $2 / 1$ & $3 / 1$ \\
\hline Location & Core & Core & Core & Core \\
\hline $\mathrm{SiO}_{2}$ & 51.47 & 51.57 & 50.36 & 51.15 \\
\hline $\mathrm{TiO}_{2}$ & 0.12 & 0.10 & 0.08 & 0.12 \\
\hline $\mathrm{Al}_{2} \mathrm{O}_{3}$ & 1.25 & 1.26 & 1.17 & 1.55 \\
\hline $\mathrm{FeO}$ & 11.61 & 9.77 & 12.31 & 13.75 \\
\hline $\mathrm{Cr}_{2} \mathrm{O}_{3}$ & 0.04 & 0.04 & 0.05 & 0.04 \\
\hline $\mathrm{MnO}$ & 0.38 & 0.45 & 0.15 & 0.20 \\
\hline $\mathrm{MgO}$ & 11.59 & 11.62 & 10.19 & 10.48 \\
\hline $\mathrm{CaO}$ & 21.37 & 22.61 & 21.61 & 20.98 \\
\hline $\mathrm{Na}_{2} \mathrm{O}$ & 0.35 & 0.40 & 0.40 & 0.38 \\
\hline $\mathrm{K}_{2} \mathrm{O}$ & 0.00 & 0.00 & 0.04 & 0.00 \\
\hline Total & 98.18 & 97.82 & 96.36 & 98.65 \\
\hline TSi & 1.981 & 1.983 & 1.986 & 1.975 \\
\hline TAl & 0.019 & 0.017 & 0.014 & 0.025 \\
\hline $\mathrm{M}_{1} \mathrm{Al}$ & 0.037 & 0.040 & 0.040 & 0.045 \\
\hline $\mathrm{M}_{1} \mathrm{Ti}$ & 0.003 & 0.003 & 0.002 & 0.003 \\
\hline $\mathrm{M}_{1} \mathrm{Fe}_{2}$ & 0.293 & 0.290 & 0.357 & 0.347 \\
\hline $\mathrm{M}_{1} \mathrm{Cr}$ & 0.001 & 0.001 & 0.002 & 0.001 \\
\hline $\mathrm{M}_{1} \mathrm{Mg}$ & 0.665 & 0.666 & 0.599 & 0.603 \\
\hline $\mathrm{M}_{2} \mathrm{Fe}_{2}$ & 0.080 & 0.024 & 0.049 & 0.097 \\
\hline $\mathrm{M}_{2} \mathrm{Mn}$ & 0.012 & 0.015 & 0.005 & 0.007 \\
\hline $\mathrm{M}_{2} \mathrm{Ca}$ & 0.881 & 0.931 & 0.913 & 0.868 \\
\hline $\mathrm{M}_{2} \mathrm{Na}$ & 0.026 & 0.030 & 0.031 & 0.028 \\
\hline Sum & 4.000 & 4.000 & 3.998 & 4.000 \\
\hline Q & 1.920 & 1.912 & 1.918 & 1.915 \\
\hline $\mathrm{J}$ & 0.052 & 0.060 & 0.061 & 0.057 \\
\hline WO & 45.605 & 48.354 & 47.478 & 45.165 \\
\hline EN & 34.415 & 34.577 & 31.150 & 31.391 \\
\hline FS & 19.980 & 17.070 & 21.371 & 23.445 \\
\hline WEF & 97.368 & 96.997 & 96.917 & 97.124 \\
\hline JD & 2.632 & 3.003 & 3.083 & 2.876 \\
\hline $\mathrm{AE}$ & 0.000 & 0.000 & 0.000 & 0.000 \\
\hline
\end{tabular}

hornblende remains low under high oxygen fugacity. In low oxygen fugacity, on the contrary, the introduction of $\mathrm{Fe}^{2+}$ is favoured in the hornblende lattice. Additionally, high $\mathrm{Fe}^{2+} / \mathrm{Fe}^{3+}$-ratio prevailing during low oxygen fugacity condition favours the substitution of $\mathrm{Mg}$ by $\mathrm{Al}$ during the tschermak substitution. So a low oxygen fugacity favours the preferential introduction of $\mathrm{Al}$ in hornblende lattice. Therefore, hornblendes with $\mathrm{Mg} \#>0.35$ and $\mathrm{Fe}^{3+} /\left(\mathrm{Fe}^{2+}+\mathrm{Fe}^{3+}\right)$-ratio $\geq 0.25$ are recommended for geobarometric calculation (Anderson and Smith 1995; Anderson 1997).

But the determination of $\mathrm{Fe}^{2+}$ and $\mathrm{Fe}^{3+}$ by stoichiometric calculations may not reflect the real 
Table 6. Electron probe microanalysis of orthopyroxene and cationic calculation on the basis of six oxygen.

\begin{tabular}{|c|c|c|c|c|c|c|c|c|c|c|}
\hline \multirow{3}{*}{$\begin{array}{l}\text { Sample } \\
\text { Rock type } \\
\text { Pluton }\end{array}$} & \multicolumn{7}{|c|}{$\mathrm{AD} 36 \mathrm{a}$} & \multicolumn{3}{|c|}{ BG24 } \\
\hline & \multicolumn{7}{|c|}{ Charnockite } & \multicolumn{3}{|c|}{ Charnoenderbite } \\
\hline & \multicolumn{7}{|c|}{ Sindurpur } & \multicolumn{3}{|c|}{ Sarpahari } \\
\hline Analysis & $1 / 1$ & $11 / 1$ & $2 / 1$ & $20 / 1$ & $21 / 1$ & $5 / 1$ & $6 / 1$ & $1 / 1$ & $4 / 1$ & $5 / 1$ \\
\hline Location & Core & Core & Rim & Core & Rim & Core & Rim & Core & Core & Core \\
\hline $\mathrm{SiO}_{2}$ & 50.05 & 50.1 & 49.74 & 49.74 & 49.46 & 47.53 & 49.36 & 49.44 & 49.69 & 49.83 \\
\hline $\mathrm{TiO}_{2}$ & 0.09 & 0.15 & 0 & 0 & 0.07 & 0 & 0.06 & 0.06 & 0.04 & 0.04 \\
\hline $\mathrm{Al}_{2} \mathrm{O}_{3}$ & 1 & 0.85 & 0.87 & 1.05 & 0.95 & 0.82 & 0.77 & 0.56 & 0.43 & 0.55 \\
\hline $\mathrm{FeO}$ & 30.72 & 31.35 & 30.33 & 31.03 & 30.69 & 30.82 & 30.81 & 35 & 35.43 & 35 \\
\hline $\mathrm{Cr}_{2} \mathrm{O}_{3}$ & 0 & 0.02 & 0.12 & 0 & 0 & 0.54 & 0.07 & 0 & 0.04 & 0 \\
\hline $\mathrm{MnO}$ & 0.63 & 0.6 & 0.61 & 0.66 & 0.51 & 0.51 & 0.65 & 0.52 & 0.55 & 0.59 \\
\hline $\mathrm{MgO}$ & 16.24 & 15.99 & 16.44 & 15.89 & 16.78 & 15.21 & 16.31 & 13.01 & 12.87 & 13.15 \\
\hline $\mathrm{CaO}$ & 0.59 & 0.55 & 0.5 & 0.49 & 0.51 & 0.52 & 0.48 & 0.36 & 0.41 & 0.46 \\
\hline $\mathrm{Na}_{2} \mathrm{O}$ & 0 & 0.05 & 0.02 & 0.02 & 0 & 0.02 & 0 & 0 & 0 & 0 \\
\hline $\mathrm{K}_{2} \mathrm{O}$ & 0 & 0 & 0 & 0 & 0 & 0.02 & 0 & 0 & 0 & 0 \\
\hline Total & 99.32 & 99.66 & 98.63 & 98.88 & 98.97 & 95.99 & 98.51 & 98.95 & 99.46 & 99.62 \\
\hline TSi & 1.956 & 1.956 & 1.954 & 1.956 & 1.934 & 1.932 & 1.945 & 1.985 & 1.988 & 1.986 \\
\hline $\mathrm{TAl}$ & 0.044 & 0.039 & 0.04 & 0.044 & 0.044 & 0.039 & 0.036 & 0.015 & 0.012 & 0.014 \\
\hline $\mathrm{M}_{1} \mathrm{Al}$ & 0.002 & 0 & 0 & 0.004 & 0 & 0 & 0 & 0.011 & 0.008 & 0.012 \\
\hline $\mathrm{M}_{1} \mathrm{Ti}$ & 0.003 & 0.004 & 0 & 0 & 0.002 & 0 & 0.002 & 0.002 & 0.001 & 0.001 \\
\hline $\mathrm{M}_{1} \mathrm{Fe}_{2}$ & 0.049 & 0.065 & 0.034 & 0.064 & 0.02 & 0.061 & 0.038 & 0.208 & 0.222 & 0.206 \\
\hline $\mathrm{M}_{1} \mathrm{Cr}$ & 0 & 0.001 & 0.004 & 0 & 0 & 0.017 & 0.002 & 0 & 0.001 & 0 \\
\hline $\mathrm{M}_{1} \mathrm{Mg}$ & 0.946 & 0.93 & 0.963 & 0.931 & 0.978 & 0.921 & 0.958 & 0.779 & 0.768 & 0.781 \\
\hline $\mathrm{M}_{2} \mathrm{Fe}_{2}$ & 0.954 & 0.959 & 0.963 & 0.956 & 0.984 & 0.986 & 0.977 & 0.967 & 0.964 & 0.96 \\
\hline $\mathrm{M}_{2} \mathrm{Mn}$ & 0.021 & 0.02 & 0.02 & 0.022 & 0.017 & 0.018 & 0.022 & 0.018 & 0.019 & 0.02 \\
\hline $\mathrm{M}_{2} \mathrm{Ca}$ & 0.025 & 0.023 & 0.021 & 0.021 & 0.021 & 0.023 & 0.02 & 0.015 & 0.018 & 0.02 \\
\hline $\mathrm{M}_{2} \mathrm{Na}$ & 0 & 0.004 & 0.002 & 0.002 & 0 & 0.002 & 0 & 0 & 0 & 0 \\
\hline Sum & 4.000 & 4.000 & 4.000 & 4.000 & 4.000 & 3.999 & 4.000 & 4.000 & 4.000 & 4.000 \\
\hline $\mathrm{Q}$ & 1.975 & 1.977 & 1.98 & 1.972 & 2.003 & 1.992 & 1.994 & 1.969 & 1.971 & 1.967 \\
\hline $\mathrm{J}$ & 0 & 0.008 & 0.003 & 0.003 & 0 & 0.003 & 0 & 0 & 0 & 0 \\
\hline WO & 1.238 & 1.152 & 1.052 & 1.035 & 1.058 & 1.127 & 1.006 & 0.779 & 0.883 & 0.988 \\
\hline $\mathrm{EN}$ & 47.409 & 46.6 & 48.126 & 46.702 & 48.423 & 45.864 & 47.54 & 39.188 & 38.587 & 39.312 \\
\hline FS & 51.354 & 52.248 & 50.822 & 52.263 & 50.519 & 53.009 & 51.455 & 60.032 & 60.529 & 59.7 \\
\hline WEF & 100 & 99.622 & 99.848 & 99.847 & 100 & 99.843 & 100 & 100 & 100 & 100 \\
\hline JD & 0 & 0 & 0 & 0.153 & 0 & 0 & 0 & 0 & 0 & 0 \\
\hline $\mathrm{AE}$ & 0 & 0.004 & 0.002 & 0 & 0 & 0.003 & 0 & 0 & 0 & 0 \\
\hline
\end{tabular}

oxygen fugacity. High oxygen fugacity condition may be retrieved from an assemblage of accessory minerals. Enami et al. (1993) suggested that occurrences of euhedral titanite and magnetite as early crystallising phases indicate high oxygen fugacity condition. In our present study, the presence of euhedral titanite, magnetite and allanite suggests high oxygen fugacity of the melt.

Other prerequisites for a correct application of the barometers are as follows: the Si-activity of the melt must have been $\mathrm{SiO}_{2}$-saturated $(\mathrm{Si} \leq 7.5$ apfu), because the Al-content of hornblende is directly related to its $\mathrm{Si}$ content; hornblendes with $\mathrm{Ca} \geq 1.6$ apfu (Hammarstrom and Zen 1986;
Bando et al. 2003); amphibole should coexist with quartz (Hammarstrom and Zen 1986) and/or Kfeldspar (Stein and Dietl 2001), because their activity also influences the $\mathrm{Al}$ content of hornblende; water saturation of the magmatic system (Anderson and Smith 1995); and plagioclase coexisting with hornblende should range between $\mathrm{An}_{25}$ and $\mathrm{An}_{35}$ (Stein and Dietl 2001).

All the analyses of amphiboles chosen for thermobarometric computations satisfy the criteria described in the preceding paragraph.

Calibrations of Johnson and Rutherford (1989) and Schmidt (1992) have been more commonly used because of their experimental derivation. A 


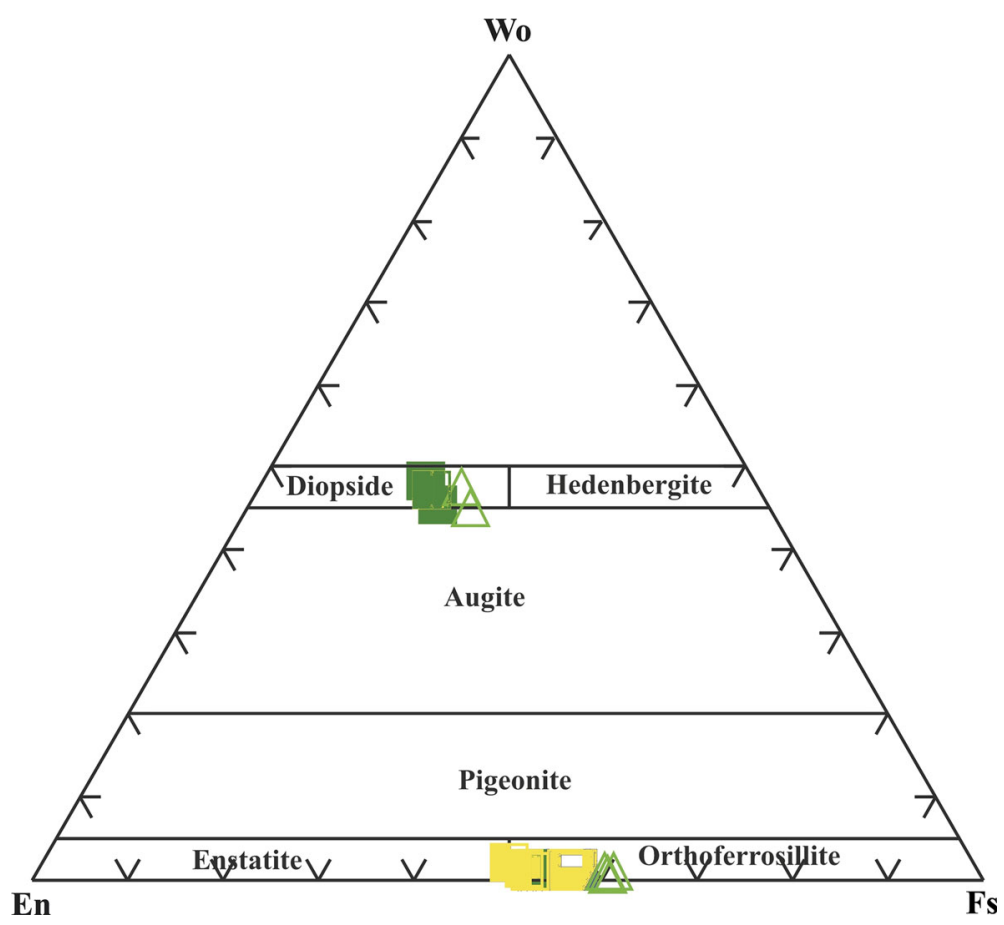

Figure 8. Nomenclature of pyroxenes of granitoids according to the IMA classification scheme (Morimoto 1988). Symbols: green open triangle - charnoenderbite, Sarpahari; green box: charnockite, Sindurpur; yellow box: enderbite, Sarpahari.

new and revised Al-in-hornblende geobarometer is recently proposed by Mutch et al. (2016) who have made an experimental study of amphibole stability in low-pressure granite magmas. Their Al-in-hornblende geobarometer is applicable to granitic rocks with the low-variance mineral assemblage: amphibole + plagioclase $\left(\mathrm{An}_{15-80}\right)+$ biotite + quartz + alkali feldspar + ilmenite/titanite + magnetite + apatite. They have recommended that amphibole analyses should be taken from the rims of grains, in contact with plagioclase and in apparent textural equilibrium with the rest of the mineral assemblage at temperatures close to the haplogranite solidus $\left(725 \pm 75^{\circ} \mathrm{C}\right)$, as determined from amphibole-plagioclase thermometry. Mean amphibole rim compositions that meet these criteria can then be used to calculate $P$ (in kbar) from $\mathrm{Al}^{\text {tot }}$ (in apfu) according to the expression:

$P($ kbar $)=0.5+0.331 \times\left(\mathrm{Al}^{\text {tot }}\right)+0.995 \times\left(\mathrm{Al}^{\text {tot }}\right)^{2}$.

Since the Agarpur pluton is emplaced in relatively shallower level (see later), this new geobarometer is used for calculation. According to the calibration of Mutch et al. (2016), the average pressure estimates for Sarpahari, Raghunathpur and Sindurpur plutons are 5.4, 5.4 and $4.5 \pm 0.5$ kbar, respectively, for the final emplacement level and crystallisation (table 7). However, following the same calibration the average pressure estimate for the Agarpur pluton yields $3.2 \pm 0.5 \mathrm{kbar}$ indicating a shallow depth of emplacement of the studied rocks.

\subsection{Temperature estimates}

Coexisting hornblende and plagioclase are commonly used for thermometric calculations in calc-alkaline igneous rocks (Blundy and Holland 1990; Holland and Blundy 1994). According to Holland and Blundy (1994), the constrains for using this thermometer are: (i) temperature should be in the range of $400-900^{\circ} \mathrm{C}$; (ii) amphiboles should have ${ }^{\mathrm{A}} \mathrm{Na}>0.02 \mathrm{pfu}, \mathrm{Al}^{\mathrm{VI}}<1.8$ pfu and $\mathrm{Si}$ in the range of $6.0-7.7 \mathrm{pfu}$; and plagioclases should have $\mathrm{X}_{\mathrm{An}}<0.90$. These compositional constraints in the studied amphiboles satisfy the use of this geothermometer. The estimate of pressure required for computation of this geothermometer is taken from Schmidt's (1992) pressure calculation. The hornblende-plagioclase geothermometer of Holland and Blundy (1994) is based on the edenite-richterite reaction and is applicable also to quartz-free igneous rocks. The average temperatures of equilibration calculated with the outer margin compositions of adjacent hornblende and plagioclase in the granitoid rocks of 


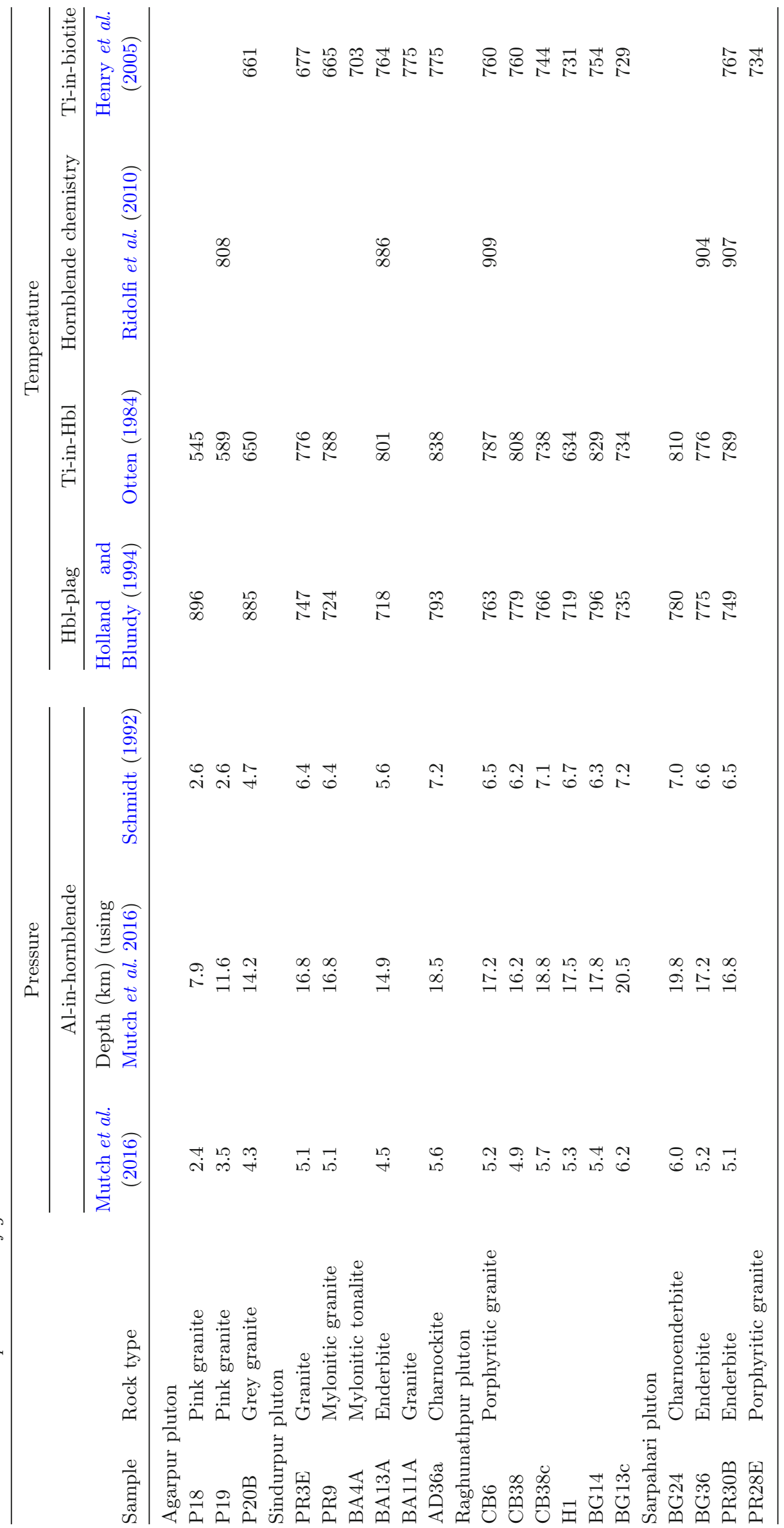




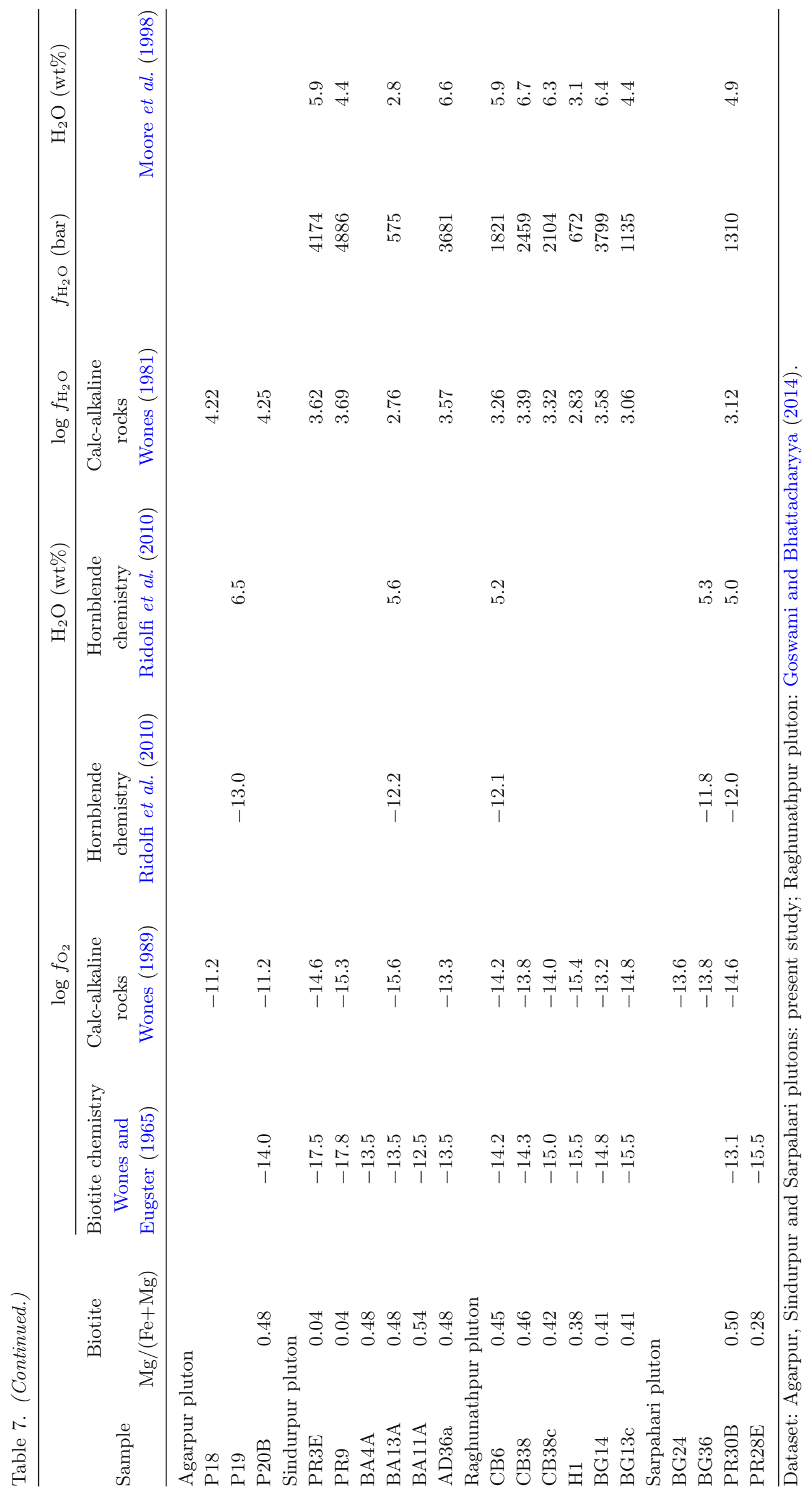


(A)

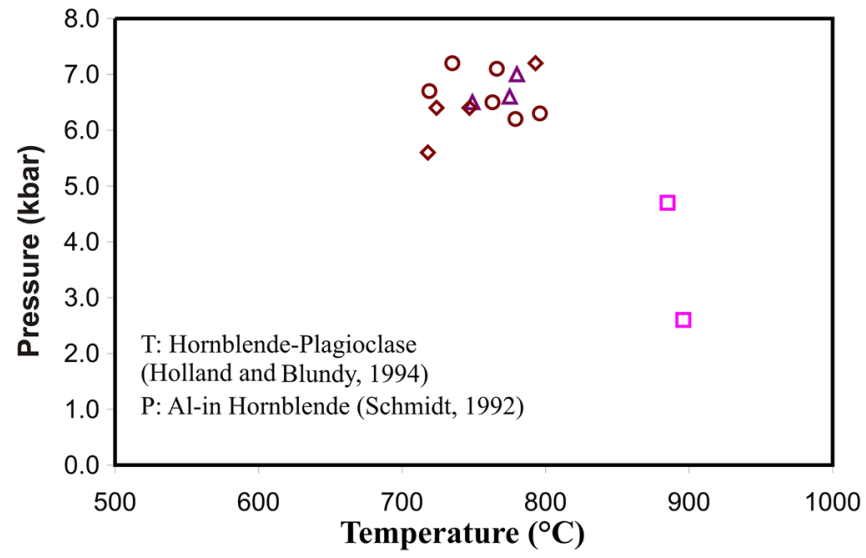

(C)

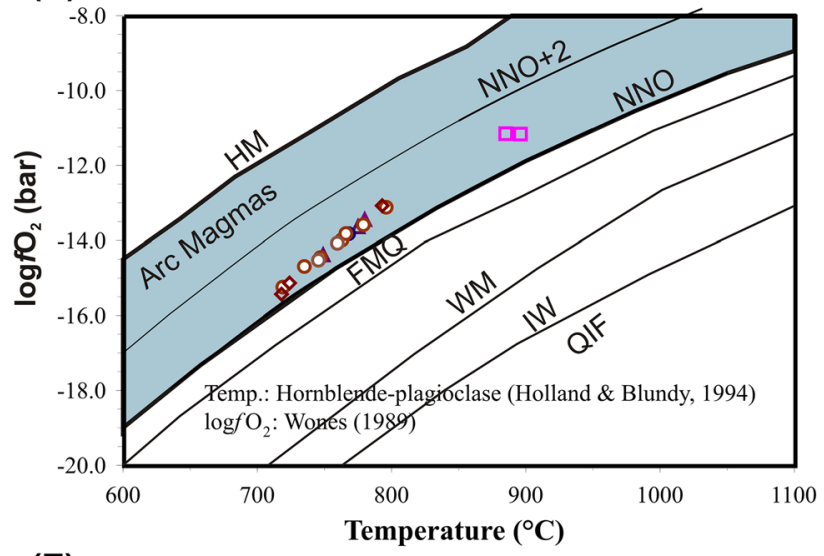

(E)

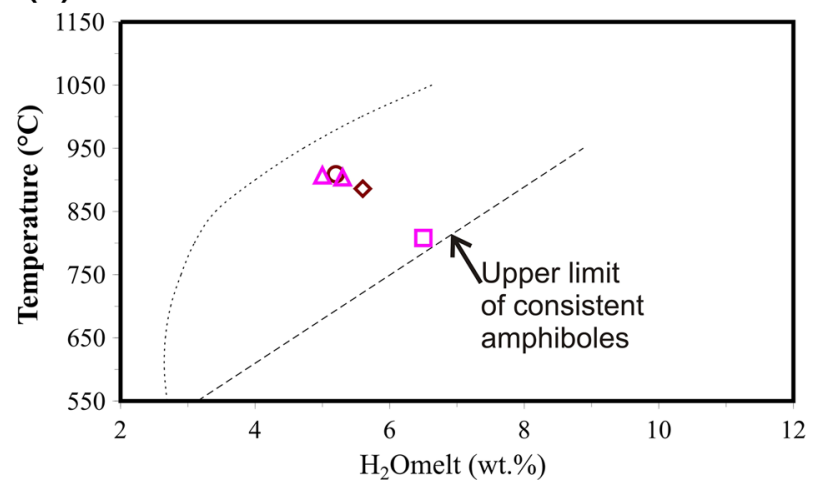

(B)

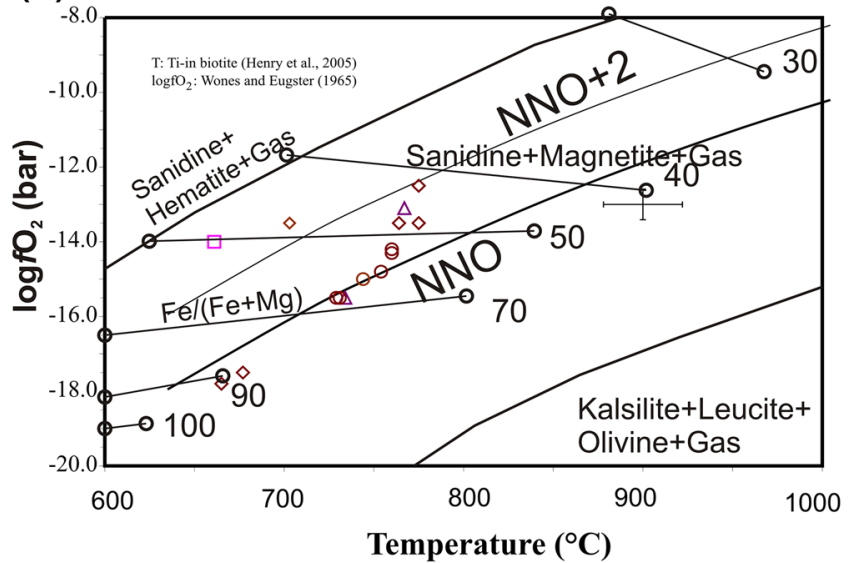

(D)

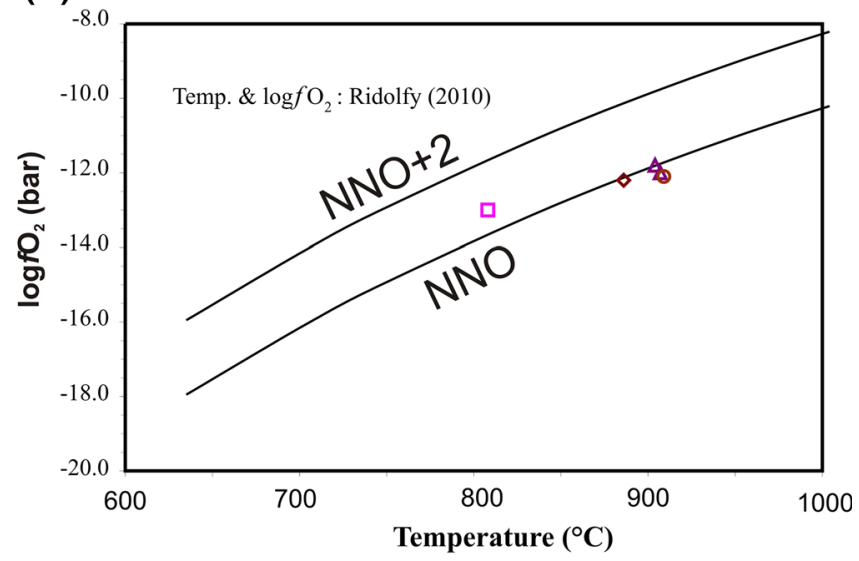

Figure 9. The $P-T$ and $T-\log f_{\mathrm{O}_{2}}$ diagrams of the selected studied amphiboles. The NNO and NNO+2 curves in $(\mathbf{B}),(\mathbf{C})$ and (D) are taken from O'Neill and Pownceby (1993). 'Arc magmas' areas from Harald and Galliard (2006). (E) A T- $\mathrm{H}_{2} \mathrm{O}$ melt diagram (after Ridolfi et al. 2010). The data source of the Raghunathpur pluton, Goswami and Bhattacharyya (2014).

Sarpahari, Raghunathpur, Sindurpur and Agarpur are $768^{\circ} \mathrm{C}, 760^{\circ} \mathrm{C}, 746^{\circ} \mathrm{C}$ and $891 \pm 40^{\circ} \mathrm{C}$, respectively (table 7 ).

Ridolfi et al. (2010) proposed a geothermometer based upon the composition of magnesian amphibole. Only a few amphibole grains are magnesian and crystallisation temperatures $\left(808-909^{\circ} \mathrm{C}\right)$ of these amphiboles are given in table 7 . Temperatures obtained using Ti-content of amphibole are also given in table 7 . A westward decrease in temperature is co-relatable with compositional variation of plutons from enderbite (Sarpahari) to monzogranite (Raghunathpur) to syenogranite (Sindurpur) to alkali feldspar granite (Agarpur) (figure 9A). This observation strongly supports that the crystallisation temperature of magma depends on the composition of the magma, especially silica content. In our study, silica content is minimum in enderbite and maximum in alkali feldspar granite. 


\subsection{Oxygen fugacity estimates}

The oxygen fugacity of magma can be calculated using the distribution coefficient of Ti from coexisting magnetite and ilmenite. But this method cannot be satisfactorily used in plutonic rocks because during slow cooling, magnetite becomes Ti-free and ilmenite undergoes oxidation and exsolution (Haggerty 1976). However, biotite is a very good indicator of the oxidation state of the magma from which it is crystallised. The coexistence of biotite, alkali feldspar and iron-titanium oxide minerals in the granites provides the basis for tentatively estimating oxygen fugacity. The $\mathrm{Ti}^{4+}$ and $\mathrm{Fe}^{3+}$ contents of biotite depend mostly on the temperature of crystallisation and oxygen fugacity $\left(f_{\mathrm{O}_{2}}\right)$ and the $\mathrm{Al}^{\mathrm{VI}}$ depends on the $\mathrm{Al}$ activity. The $\mathrm{Fe}^{3+}$ content and $\mathrm{Fe}^{\mathrm{t}} /\left(\mathrm{Fe}^{\mathrm{t}}+\mathrm{Mg}\right)$ ratio provide at least the relative information about the oxygen fugacity during crystallisation (Wones and Eugster 1965). Since $\mathrm{Fe}^{3+}$ and $\mathrm{Fe}^{2+}$ cannot be estimated by EPMA, a quantitative estimation of the oxygen fugacity or temperature can be obtained using the experimental work of Wones and Eugster (1965) modified by Shabani et al. (2003) for biotites coexisting with magnetite and alkali feldspar. The crystallisation temperatures of biotites of the present study have been obtained from the calibration of Henry et al. (2005), where Ti-content of biotite was used (table 7; figure 9B).

The rocks of the present study show oxygen fugacity between $\mathrm{NNO}$ and $\mathrm{NNO}+2$ buffers which is consistent with the presence of sphene, allanite and magnetite/ilmenite. In this diagram, the NNO and NNO +2 curves were obtained from O'Neill and Pownceby (1993). The Sarpahari enderbites equilibrated at an oxygen fugacity $\left(\log f_{\mathrm{O}_{2}}\right)$ between -13.4 and -14.4 bar, for the temperatures of crystallisation interval between $780^{\circ}$ and $749^{\circ} \mathrm{C}$. In porphyritic monzogranites of the Raghunathpur, the oxygen fugacity $\left(\log f_{\mathrm{O}_{2}}\right.$ ) varies between -13.1 and -15.2 bar for crystallisation temperature range between $796^{\circ}$ and $719^{\circ} \mathrm{C}$. The rocks of Sindurpur show more or less similar range of oxygen fugacity $\left(\log f_{\mathrm{O}_{2}}\right)$ between -13.1 and -15.4 bar for a temperature range between $793^{\circ}$ and $718^{\circ} \mathrm{C}$. The oxygen fugacity is quite high for the Agarpur pluton and is about -11.2 bar at a temperature range between $885^{\circ}$ and $896^{\circ} \mathrm{C}$.

Wones (1989) suggests a quantitative estimation of oxygen fugacity of granitoid rocks with assemblage sphene + magnetite + quartz.
Equilibrium expression of Wones (1989) is used in the present study to estimate the prevailing oxygen fugacity in the different plutons (table 7 ). Temperatures and pressures estimated from hornblende-plagioclase thermometry (Holland and Blundy 1994) and aluminium-in-hornblende barometry (Schmidt 1992) were used to calculate $\log f_{\mathrm{O}_{2}}$ of the magma following Wones (1989) expression (figure 9C).

Ridolfi et al. (2010) proposed an empirical universal amphibole sensor to estimate temperature and $\log f_{\mathrm{O}_{2}}$ parameters. However, only a few data of the present study admit the validity level. The present study depicts (figure 9d) the slightly increasing oxygen fugacity trend with decreasing temperature. Following the calibration of Ridolfi et al. (2010), the calculated range of values of $\log f_{\mathrm{O}_{2}}$ for Sarpahari enderbite rocks are found to be -11.8 and -12.0 bar. In Raghunathpur, porphyritic granitoids and Sindurpur granites, the $\log f_{\mathrm{O}_{2}}$ are found to be -12.1 and -12.2 bar, respectively, at about $900^{\circ} \mathrm{C}$. According to Ridolfi et al.'s (2010) calibration, the oxygen fugacity (log $f_{\mathrm{O}_{2}}$ ) of the Agarpur pluton is about -13 bar at $808^{\circ} \mathrm{C}$ temperature.

\subsection{Hygrometric estimates}

The assemblage biotite-K-feldspar-magnetite acts as a buffer of oxygen and water fugacities in the magma (Wones and Eugster 1965; Czamanske and Wones 1973):

$$
\begin{aligned}
& \mathrm{KFe}_{3} \mathrm{AlSi}_{3} \mathrm{O}_{10}(\mathrm{OH})_{2}+0.5 \mathrm{O}_{2} \\
& =\mathrm{KAlSi}_{3} \mathrm{O}_{8}+\mathrm{Fe}_{3} \mathrm{O}_{4}+\mathrm{H}_{2} \mathrm{O} .
\end{aligned}
$$

Annite activity (aann) of biotite reflects the fugacities of oxygen and water in magma. In a crystallising magma, the $a_{\mathrm{H}_{2} \mathrm{O}}$ increases with decreasing $T$ due to crystallisation of anhydrous phases. Concomitantly, when $f_{\mathrm{O}_{2}}$ of the magma is buffered, annite in biotite increase through reaction of $\mathrm{K}$ feldspar with magnetite, with resulting growth of the $\mathrm{Fe}^{2+} /\left(\mathrm{Fe}^{2+}+\mathrm{Mg}\right)$ ratio. At the constant temperature and constant $f_{\mathrm{H}_{2} \mathrm{O}}$, when $f_{\mathrm{O}_{2}}$ decreases, annite of biotite also increases either by a decrease of $\mathrm{Fe}^{3+} / \mathrm{Fe}_{\text {tot }}$ or by an increase of $\mathrm{Fe}^{2+} /\left(\mathrm{Fe}^{2+}+\mathrm{Mg}\right)$ ratios. If $f_{\mathrm{O}_{2}}$ of the magma and activities of magnetite and K-feldspar are known, the activity of annite in biotite may be used to derive the water fugacity through the reaction (Wones 1972; Czamanske and Wones 1973): 


$$
\begin{aligned}
\log f_{\mathrm{H}_{2} \mathrm{O}}= & 7409 / T+4.25+0.5 \log f_{\mathrm{O}_{2}}+\log a_{\mathrm{ann}} \\
& -\log a_{\mathrm{Kf}}-\log a_{\mathrm{mag} .}
\end{aligned}
$$

Later on, Wones (1981) revised it as

$$
\begin{aligned}
\log f_{\mathrm{H}_{2} \mathrm{O}}= & 4819 / T+6.69+0.5 \log f_{\mathrm{O}_{2}}+\log a_{\mathrm{ann}} \\
& -\log a_{\mathrm{Kf}}-\log a_{\mathrm{mag}}-0.011(P-1) / T,
\end{aligned}
$$

where $T$ is in kelvin and activities are given as molar fractions. The activity of annite in biotite can be calculated by various ideal activity models (Mueller 1972; Wones 1972; Czamanske and Wones 1973; Bohlen et al. 1980; Holland and Powell 1990; Nash 1993; Patińo Douce 1993). The activity of K-feldspar is 0.6 for magmatic temperatures (Czamanske and Wones 1973) and activity of most re-equilibrated magnetites is close to 1 . The $f_{\mathrm{H}_{2} \mathrm{O}}$ then can be calculated using the Wones' (1981) equation. The water activity of magma can be given by

$$
a_{\mathrm{H}_{2} \mathrm{O}}=f_{\mathrm{H}_{2} \mathrm{O}} / f^{0}{ }_{\mathrm{H}_{2} \mathrm{O}},
$$

where $f^{0}{ }_{\mathrm{H}_{2} \mathrm{O}}$ is the standard state water fugacity.

On the basis of water solubility models of Burnham (1979) and Burnham and Nekvasil (1986), it is possible to convert the $a_{\mathrm{H}_{2} \mathrm{O}}, f_{\mathrm{H}_{2} \mathrm{O}}$ to $X_{\mathrm{H}_{2} \mathrm{O}}$, which can then be expressed in wt\%. We use the empirical model of Moore et al. (1998) for determining the $\mathrm{H}_{2} \mathrm{O}$ (wt\%) from $f_{\mathrm{H}_{2} \mathrm{O}}$ (vapour) in magmas. This model can be applied between $700^{\circ}$ and $1200^{\circ} \mathrm{C}$ and 1-3000 bar and can be applied to any natural silicate liquid in that range. For the conversion of $f_{\mathrm{H}_{2} \mathrm{O}}$ to $\mathrm{H}_{2} \mathrm{O}$ (wt\%), the following regression equation is derived from the experimental data of Moore et al. (1998):

$$
\begin{aligned}
\mathrm{H}_{2} \mathrm{O}(\mathrm{wt} \%)= & -7 \times 10^{7}\left(f_{\mathrm{H}_{2} \mathrm{O}}\right)^{2}+0.0042\left(f_{\mathrm{H}_{2} \mathrm{O}}\right) \\
& +0.5798 .
\end{aligned}
$$

The $f_{\mathrm{H}_{2} \mathrm{O}}$ of the Sindurpur pluton is estimated to be $575-4886$ bar corresponding to $2.8-6.6$ wt $\%$ of water in the magma (table 7 ). The Raghunathpur pluton gives a more consistent $f_{\mathrm{H}_{2} \mathrm{O}}$ values ranging between 672 and 3799 bar corresponding to 3.1 and $6.7 \mathrm{wt} \%$ of water. One sample of the Sarpahari pluton has requisite assemblage and gives $f_{\mathrm{H}_{2} \mathrm{O}}$ value at 1310 bar corresponding to $4.9 \mathrm{wt} \%$ of water in the magma. Very high $\log f_{\mathrm{H}_{2} \mathrm{O}}$ values are obtained from the samples of the Agarpur pluton and these values are out of range of experimental values of Moore et al. (1998).
The water content of magma can also be obtained by the empirical calibration of Ridolfi et al. (2010) using magnesiohornblende composition. According to the amphibole hygrometer of Ridolfi et al. (2010), the water contents in the Sarpahari pluton range from 5.0 to $5.3 \mathrm{wt} \%$ (table 7). The water contents of Raghunathpur, Sindurpur and Agarpur plutons were about 5.2, 5.6 and $6.5 \mathrm{wt} \%$, respectively. These values are in conformity with the typical values of calc-alkaline magma crystallisation in an arc-related environment (figure 9E; Ridolfi et al. 2010).

Like temperature, a slight increase in water content of magmas of different plutons from east to west, enderbite of Sarpahari in the east, monzogranite of Raghunathpur, syenogranite of Sindurpur and alkali feldspar granite of Agarpur to the west is noticed which is correlatable with the change in magma composition.

\section{Nature of magma}

In the present study, biotite compositions are used as effective tools for fingerprinting the magma type and potentially reflecting the nature of the magma and tectonic environment in which they are formed (e.g., Nachit et al. 1985; Abdel-Rahman 1994). Biotites from different granites are aluminous $\left(\mathrm{Al}_{\text {total }}=3.01-3.54 \mathrm{apfu}\right)$ and ferric $\left(\mathrm{X}_{\mathrm{Mg}}=\right.$ 0.36-0.47), typical of biotites from subalkaline to calc-alkaline to aluminopotassic granites (table 2; figure 10A). Biotite compositions show a continuous increase in $\mathrm{Al}_{\text {total }}$ and decrease in $\mathrm{Mg}$ from eastern to western plutons, i.e., from Sarpahari to Agarpur granites. The progressive increase of the total $\mathrm{Al}$ contents and the $\mathrm{Fe}^{2+} /\left(\mathrm{Fe}^{2+}+\mathrm{Mg}\right)$ ratios in biotite (figure 10A) are consistent with a compositional trend of biotite in continental collision-related granites (Lalonde and Bernard 1993). It indicates the contribution of crustal material (metasediments) during the petrogenesis of the granitoid magmas, either by assimilation or anatexis (Shabani et al. 2003).

Biotites of the Agarpur pluton show $\mathrm{FeO} / \mathrm{MgO}$ ratios in the 1.92-2.05 range and plot well within the calc-alkaline field of the $\mathrm{MgO}-\mathrm{FeO}-\mathrm{Al}_{2} \mathrm{O}_{3}$ discrimination diagram (figure 10B).

Although the $\mathrm{FeO} / \mathrm{MgO}$ ratios of biotite analysed from the Sindurpur pluton are moderately enriched in $\mathrm{Mg}$, showing $\mathrm{FeO} / \mathrm{MgO}$ ratios ranging from 1.38 to 2.26 , these plot within the calc-alkaline field in the $\mathrm{MgO}-\mathrm{FeO}-\mathrm{Al}_{2} \mathrm{O}_{3}$ diagram. However, 
(A)

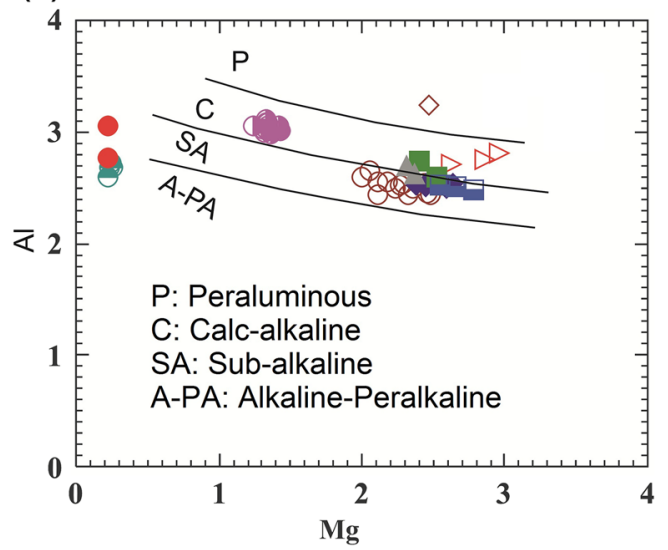

(B)

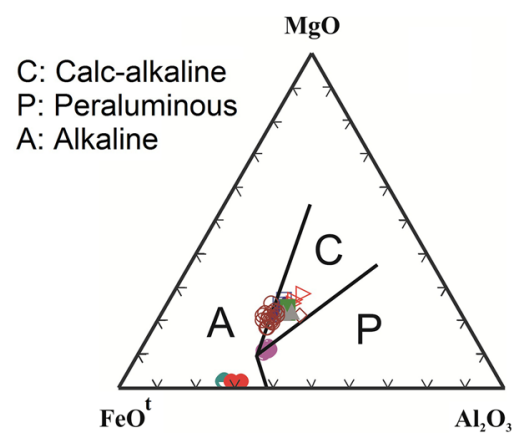

Figure 10. (A) $\mathrm{Al}_{\text {total }}$ vs. $\mathrm{Mg}$ (p.f.u.) diagram (Nachit et al. 1985) for biotites of the present study. (B) $\mathrm{Al}_{2} \mathrm{O}_{3}-\mathrm{FeO}^{\mathrm{t}}-$ $\mathrm{MgO}$ discrimination diagram for distinguishing the nature of the granitoids of northern Purulia (Abdel-Rahman 1994). $\mathrm{FeO}^{t}=\left[\mathrm{FeO}+\left(0.89981 * \mathrm{Fe}_{2} \mathrm{O}_{3}\right)\right]$. The data source of the Raghunathpur pluton: Goswami and Bhattacharyya (2014).

higher $\mathrm{FeO} / \mathrm{MgO}$ values (38.85-42.22) are obtained from biotites of Sindurpur and Tilaboni hillocks. In the $\mathrm{MgO}-\mathrm{FeO}-\mathrm{Al}_{2} \mathrm{O}_{3}$ discrimination diagram (Abdel-Rahman 1994), the most biotites from the Sindurour pluton fall within the calc-alkaline field and some samples plot in the alkaline suite field (figure 10B). Biotites of the Raghunathpur pluton show the most consistent variation in $\mathrm{FeO} / \mathrm{MgO}$ ratio (2.08-2.96) and all the analysed biotites are plotted on the boundary between calc-alkaline and alkaline granitoid fields in the $\mathrm{MgO}-\mathrm{FeO}-\mathrm{Al}_{2} \mathrm{O}_{3}$ discrimination diagram of Abdel-Rahman (1994) (figure 10B).

An enderbite sample of the Sarpahari pluton shows $\mathrm{FeO} / \mathrm{MgO}$ ratios of biotites in the range 1.65-1.86 which are consistent with the calcalkaline nature of the magma. But porphyritic granitoids from the same pluton show relatively high $\mathrm{FeO} / \mathrm{MgO}$ values (4.49-5.47), consistent with the peraluminous nature of the magma (figure 10B).

\section{Tectonic implications}

\subsection{Implications of biotite composition}

Biotite compositions clearly define the nature of magmas from which they have been crystallised. In the $\mathrm{MgO}-\mathrm{FeO}-\mathrm{Al}_{2} \mathrm{O}_{3}$ discrimination diagram of Abdel-Rahman (1994), biotites of the Agarpur pluton plot well within the calc-alkaline field (figure 10B). Most of the biotites from the Sindurpur pluton also fall within the calc-alkaline field and some samples plot in the alkaline suite field, while biotites of the Raghunathpur pluton are plotted on the boundary between calc-alkaline and alkaline granitoid fields. Similarly, enderbites of Sarpahari plutons are plotted in the field of calcalkaline granite (figure 10A). Biotite chemistry of four plutons of the present study suggests that they were formed from subduction-related calc-alkaline magma (Abdel-Rahman 1994).

\subsection{Implications of pressure estimate}

In the present study, the Al-in-hornblende barometer (Mutch et al. 2016) is used to understand the vertical crustal upliftment on a regional scale, after complete solidification of the magma because the calculated pressures probably represent conditions during final emplacement (Stein and Dietl 2001).

Although different samples from the same pluton may give different depths of emplacement, a systematic variation of general depth of emplacement is discernable from the eastern to western part of the study area. Moreover, calculations of intrinsic parameters (table 7 ) enable us to realise the following conclusions:

(i) The Raghunathpur pluton and Sindurpur pluton are separated by E-W trending NPSZ and these plutons are located north and south of the shear zone (figure 1B). Slightly deeper emplacement of the Raghunathpur pluton $(16.2-20.5 \mathrm{~km})$ relative to the Sindurpur pluton $(14.9-18.5 \mathrm{~km})$ suggests that negligible vertical upliftment might have taken place on the northern block relative to the southern block. This is consistent with the field 
observation that NPSZ is a sinistral strike-slip shear zone with minute dip-slip component.

(ii) The Sarpahari pluton $(16.8-19.8 \mathrm{~km})$ which is located about $60 \mathrm{~km}$ ENE from the Agarpur pluton (7.9-14.2 km) must have been uplifted 5-8 $\mathrm{km}$ relative to the latter pluton. This, in turn, suggests a weak ENE trend of increasing depth of emplacement (figure 1B).

\subsection{Implication of oxygen fugacity}

The oxygen fugacity of magma is related to its source material and tectonic settings. Sedimentderived S-type granitic magmas are usually reduced, while I-type granites are relatively oxidised (Haggerty 1976). Highly oxidised magmas are commonly associated with convergent plate boundaries (Ewart 1979), while felsic magmas that are formed by fractionation from mantle-derived magmas in rift zones are reduced (Loiselle and Wones 1979). Hammarstrom and Zen (1986) suggest that calcic amphibole crystallised under fairly 'oxidising' conditions, with $f_{\mathrm{O}_{2}}$ probably buffered between NNO and HM. The oxygen fugacity $\left(\log f_{\mathrm{O}_{2}}\right)$ values calculated from the calcic amphiboles by means of Ridolfi et al.'s (2010) formula varied between -11.8 and -13.0 bar (figure 9D), and all of the samples are plotted in the arc magma field described by Harald and Galliard (2006). These values show a relatively high oxidation state (higher than NNO buffer condition) during the late-stage crystallisation of biotite and show a trend for magma crystallisation in oxidising conditions (figure 9C).

\subsection{Implication of water activity}

The concentration of $\mathrm{H}_{2} \mathrm{O}_{\text {melt }}$ in the studied plutons ranges from 5.0 to $6.5 \%$ (as estimated following Ridolfi et al. 2010) and from 2.8 to $7.01 \%$ (as estimated following Moore et al. 1998). These values are in conformity with the typical values of calc-alkaline magma generated in an arc-related environment (Naney 1983).

\section{Conclusions}

The fabric of the four granitoid plutons (Sarpahari, Raghunathpur, Sindurpur, and Agarpur) from northern Purulia is interpreted to be primarily of igneous origin. The marginal parts of these plutons were affected by regional shearing. However, the chemical compositions of the magmatic minerals of the central parts of the plutons, from where samples were collected, have not been altered due to shearing at the marginal parts.

The mineral compositions of these plutons were used to estimate the physico-chemical parameters of the crystallisation conditions of the parent magmas and also to establish the chemical nature of parent magma and the tectonic environment in which these plutons were emplaced.

Biotite compositions of all the four plutons of the present study suggest that these were crystallised from subduction-related calc-alkaline magma (Abdel-Rahman 1994).

The pressure of emplacement of these plutons was estimated using Al-in-hornblende barometry (Mutch et al. 2016; table 7). Slight pressure difference of emplacement of Raghunathpur (4.9 and $6.2 \mathrm{kbar})$ and Sindurpur plutons (4.5-5.6 kbar) lying north and south of NPSZ, respectively, suggests that vertical upliftment along shear zone was negligible and the strike-slip movement was dominant in the shear zone. The Sarpahari pluton $(P=5.1-6.0$ kbar $)$ which is located about $60 \mathrm{~km}$ ENE from the Agarpur pluton $(P=2.4$ $4.3 \mathrm{kbar}$ ) must have been uplifted $5-8 \mathrm{~km}$ relative to the latter pluton. This, in turn, suggests a weak ENE trend of increasing depth of emplacement.

The average temperatures of equilibration calculated by the method of Holland and Blundy (1994) using compositions of adjacent hornblende and plagioclase in the granitoid rocks of Sarpahari, Raghunathpur, Sindurpur and Agarpur are $768^{\circ}, 760^{\circ}, 746^{\circ}$ and $891 \pm 40^{\circ} \mathrm{C}$, respectively. The crystallisation temperatures of biotites of the present study have been obtained from the calibration of Henry et al. (2005), where Ti-content of biotite was used and showed a systematic variation from Sarpahari $\left(734^{\circ}-767^{\circ} \mathrm{C}\right)$, Ragunathpur $\left(729^{\circ}-760^{\circ} \mathrm{C}\right)$, Sindurpur $\left(677^{\circ}-775^{\circ} \mathrm{C}\right)$ to Agarpur $\left(661^{\circ} \mathrm{C}\right)$.

The four plutons of the present study have been equilibrated at the oxygen fugacities of calcic amphiboles $\left(\log f_{\mathrm{O}_{2}}\right)$ between -11.8 and -13.0 bar (using calibration of Ridolfi et al. 2010). The assemblage K-feldspar-biotite-magnetite-quartzsphene displays consistent oxygen fugacity values ( $\log f_{\mathrm{O}_{2}}=-11.2$ to -15.6 bar) (using calibration of Wones 1989) typical for the calc-alkaline magma crystallisation.

The water content of the melt $\left(\mathrm{H}_{2} \mathrm{O}_{\text {melt }}\right)$ ranges from 5.0 to $6.5 \%$ for the four plutons.

The high oxygen fugacity (higher than $\mathrm{Ni}-\mathrm{NiO}$ buffer) and high water content of the parental 
granitoid magma are consistent with their emplacement in a subduction zone.

\section{Acknowledgements}

Major research project grant of the UGC [F.-43$367 / 2014(\mathrm{SR})]$ and research grant of the University of Calcutta given to B Goswami are gratefully acknowledged. Thanks are due to Prof. Chalapathy Rao and Dr Dinesh Pandit (Department of Geology, Benaras Hindu University) and Dr S Nandy, Sri S K Tripathy and Sri Narahari (EPMA Laboratory, CHQ, GSI, Kolkata) for providing electron microprobe facilities. Painstaking reviews by three anonymous reviewers and their most valuable suggestions helped to improve this paper to a great extent. Supportive editorial handling by Prof. Rajesh Kumar Srivastava and Prof. Chalapathy Rao (Chief editor) is gratefully acknowledged.

\section{References}

Abdel-Rahman A F M 1994 Nature of biotites from alkaline, calc-alkaline, and peraluminous magmas; J. Petrol. 35(2) 525-541.

Ague J J 1997 Thermodynamic calculation of emplacement pressures for batholithic rocks, California: Implications for the aluminum-in-hornblende barometer; Geology 25 563566.

Anderson J L 1996 Status of thermobarometry in granitic batholiths; Trans. Roy. Soc. Edinb. (Earth Sci.) 87 125138.

Anderson J L 1997 Regional tilt of the Mount Stuart batholith, Washington, determined using aluminum-inhornblende barometry: Implications for northward translation of Baja British Columbia: Discussion; Bull. Geol. Soc. Am. 109 1223-1227.

Anderson J L and Smith D R 1995 The effects of temperature and $f_{\mathrm{O}_{2}}$ on the Al-in-hornblende barometer; Am. Mineral. 80(5-6) 549-559.

Bando M, Bignall G, Sekine K and Tsuchiya N 2003 Petrography and uplift history of the Quaternary Takidani granodiorite: Could it have hosted a supercritical (HDR) geothermal reservoir?; J. Volcanol. Geotherm. Res. 120(3) 215-234.

Banerji A K 1991 Geology of the Chhotanagpur region; Ind. J. Geol. 63 275-282.

Basu S K 1993 Alkaline-carbonatite complex in Precambrian of south Purulia Shear Zone, eastern India: Its characteristics and mineral potentialities; Ind. Mineral. 47(3) 179-194.

Blundy J D and Holland T J 1990 Calcic amphibole equilibria and a new amphibole plagioclase geothermometer; Contrib. Mineral. Petrol. 104(2) 208-224.
Bohlen S R, Essene E J and Boettcher A L 1980 Reinvestigation and application of olivine-quartzorthopyroxene barometry; Earth Planet. Sci. Lett. 47(1) $1-10$.

Bohlender F, Van Reenen D D and Barton Jr J M 1992 Evidence for metamorphic and igneous charnockites in the Southern Marginal Zone of the Limpopo Belt; Precamb. Res. 55(1-4) 429-449.

Brown M and Solar G S 1998 Granite ascent and emplacement during contractional deformation in convergent orogens; J. Struct. Geol. 20(9/10) 1365-1393.

Burnham C W 1979 The importance of volatile constituents; In: The evolution of the igneous rocks: Fiftieth anniversary perspectives (ed.) Yoder H S Jr, Princeton University Press, Princeton, N.J., pp. 439-482.

Burnham C W and Nekvasil H 1986 Equilibrium properties of granite pegmatite magmas; Am. Mineral. 71(3-4) 239 263.

Czamanske G K and Wones D R 1973 Oxidation during magmatic differentiation, Finnmarka complex, Oslo area, Norway; Part 2, the mafic silicates1; J. Petrol. 14(3) 349380.

Deer W A, Howie R A and Zussman J 1997 Rock-Forming Minerals Double-Chain Silicates; Volume 2B, 2nd edn, The Geological Society, UK, 758p.

Deer W A, Howie R A and Zussman J 1992 An introduction to the rock-forming minerals; Longman, London, $696 \mathrm{p}$.

Douce A E P 1993 Titanium substitution in biotite: An empirical model with applications to thermometry, $\mathrm{O}_{2}$ and $\mathrm{H}_{2} \mathrm{O}$ barometries, and consequences for biotite stability; Chem. Geol. 108(1-4) 133-162.

Enami M, Zang Q and Yin Y 1993 High-pressure eclogites in northern Jiangsu-southern Shandong province, eastern China; J. Metamorph. Geol. 11(4) 589-603.

Ewart 1979 A review of the mineralogy and chemistry of Tertiary-recent dacitic, latitic, rhyolitic and related salic volcanic rocks; In:Trondhjemites, dacites, and related rocks (ed.) Fred B, Springer-Verlag Berlin, 12 101.

Frost B R, Frost C D, Hulsebosch T P and Swapp S M 2000 Origin of the charnockites of the Louis lake Batholith, wind River Range, Wyoming; J. Petrol. 41(12) 17591776

Ghose N C 1983 Geology, tectonics and evolution of the Chhotanagpur granite gneiss complex, eastern India; In: Structure and tectonics precambrian rocks India, Rec. Res. Geol. 10 211-247.

Ghose N C 1992 Chhotanagpur gneiss-granulite complex, eastern India: Present status and future prospect; Ind. J. Geol. 64(1) 100-121.

Goswami B and Bhattacharyya C 2008 Tectonothermal evolution of Chhotanagpur Granite Gneiss complex from northeastern part of Puruliya district, West Bengal, eastern India; Ind. J. Geol. 80(1-4) 41-54.

Goswami B and Bhattacharyya C 2014 Petrogenesis of shoshonitic granitoids, eastern India: Implications for the late Grenvillian post-collisional magmatism; Geosci. Frontiers 5(6) 821-843.

Haggerty S E 1976 Oxidation of opaque mineral oxides in basalts; In: Reviews in Mineralogy - Oxide Minerals (ed.) Rumble D, Min. Soc. Amer. 3 1-100. 
Hammarstrom J M and Zen E A 1986 Aluminum in hornblende: An empirical igneous geobarometer; Am. Miner. 71(11-12) 1297-1313.

Harald B and Galliard F 2006 Geochemical aspects of melts: Volatiles and redox behaviour; Elements 2(5) 275-280.

Henry D J, Guidotti C V and Thomson J A 2005 The Ti-saturation surface for low-to-medium pressure metapelitic biotites: Implications for geothermometry and Ti-substitution mechanisms; Am. Mineral. 90(2-3) 316328.

Holland T and Blundy J 1994 Non-ideal interactions in calcic amphiboles and their bearing on amphibole-plagioclase thermometry; Contrib. Mineral. Petrol. 116(4) 433447.

Holland T J B and Powell R 1990 An enlarged and updated internally consistent thermodynamic dataset with uncertainties and correlations: The system $\mathrm{K}_{2} \mathrm{O}-\mathrm{Na}_{2} \mathrm{O}-$ $\mathrm{CaO}-\mathrm{MgO}-\mathrm{MnO}-\mathrm{FeO}-\mathrm{Fe}_{2} \mathrm{O}_{3}-\mathrm{Al}_{2} \mathrm{O}_{3}-\mathrm{TiO}_{2}-\mathrm{SiO}_{2}-\mathrm{C}-\mathrm{H}_{2}-$ $\mathrm{O}_{2}$; J. Metamorph. Geol. 8(1) 89-124.

Hunter R H 1987 Textural equilibrium in layered igneous rocks; In: Origins of igneous layering, Springer, Dordrecht, pp. 473-503.

Hutton D H W 1988 Granite emplacement mechanisms and tectonic controls: Inferences from deformation studies; Trans. Roy. Soc. Edinburgh (Earth Sci.) 79 245-255.

Johnson M C and Rutherford M J 1989 Experimental calibration of the aluminum-in-hornblende geobarometer with application to Long Valley caldera (California) volcanic rocks; Geology 17 837-841.

Kramers J D and Ridley J R 1989 Can Archean granulites be direct crystallization products from a sialic magma layer? Geology 17(5) 442-445.

Lalonde A E and Bernard P 1993 Composition and color of biotite from granites: Two useful properties in the characterization of plutonic suites from the Hepburn internal zone of Wopmay orogen, Northwest Territories; Can. Mineral. 31 203-217.

Leake R E 1971 On aluminous and edentic hornblendes; Min. Mag. 38 389-407.

Leake B E, Woolley A R, Arps C E, Birch W D, Gilbert M C, Grice J D, Hawthorne F C, Kato A, Kisch H J, Krivovichev V G. and Linthout K 1997 Report. Nomenclature of amphiboles: Report of the subcommittee on amphiboles of the international mineralogical association commission on new minerals and mineral names; Mineral. Mag. 61(2) 295-321.

Loiselle M C and Wones D R 1979 Characteristics and origin of anorogenic granites; Abstracts of papers to be presented at the Annual Meetings of the Geological Society of America and Associated Societies, San Diego, California, November, 11468.

Maaløe S 1985 Principles of Igneous Petrology; SpringerVerlag, New York, 374p.

Mahadevan T M 2002 Geology of Bihar and Jharkhand; Geological Society of India, Bangalore, p. 563.

Maji A K, Goon S, Bhattacharya A, Mishra B, Mahato S and Bernhardt H J 2008 Proterozoic polyphase metamorphism in the Chhotanagpur Gneissic Complex (India), and implication for trans-continental Gondwanaland correlation; Precamb. Res. 162(3) 385-402.

Mitra (Bhaumik) T 1992 An appraisal of the evolution of the Raghunathpur-Santuri-Saltora tract, Purulia-Bankura districts, West Bengal - a high grade enclave within Chhotanagpur plateaus; Ind. J. Geol. 64(4) 339-353.

Moore G, Vennemann T and Carmichael I S E 1998 An empirical model for the solubility of $\mathrm{H}_{2} \mathrm{O}$ in magmas to 3 kilobars; Am. Mineral. 83(1-2) 36-42.

Morimoto N 1988 Nomenclature of pyroxenes; Mineral. Petrol. 39(1) 55-76.

Mueller R F 1972 Stability of biotite: A discussion; Am. Mineral. 57(1-2) 300-316.

Mutch E J F, Blundy J D, Tattitch B C, Cooper F J and Brooker R A 2016 An experimental study of amphibole stability in low-pressure granitic magmas and a revised Al-in-hornblende geobarometer; Contrib. Mineral. Petrol. 171(10) 85 .

Nachit H, Razafimahefa N, Stussi J M and Carron J P 1985 Composition chimique des biotites et typologie magmatique des granitoldes; Comptes Rendus Hibdomadaires de l'Acadimie des Sci. Paris 301(11) 813-818.

Nachit H, Ibhi A, Abia E H and Ohoud M B 2005 Discrimination between primary magmatic biotites, reequilibrated biotites and neoformed biotites; C.R. Geosci. 337(16) $1415-1420$.

Naney M T 1983 Phase equilibria of rock-forming ferromagnesian silicates in granitic systems; Am. J. Sci. $\mathbf{2 8 3}$ 993-1033.

Nash W P 1993 Fluorine iron biotite from the Honeycomb Hills rhyolite, Utah: The halogen record of decompression in a silicic magma; Am. Mineral. 78 1031-1040.

O'Neill H S C and Pownceby M I 1993 Thermodynamic data from redox reactions at high temperatures. I. An experimental and theoretical assessment of the electrochemical method using stabilized zirconia electrolytes, with revised values for the $\mathrm{Fe}-\mathrm{FeO}, \mathrm{Co}-\mathrm{CoO}, \mathrm{Ni}-\mathrm{NiO}$ and $\mathrm{Cu}-\mathrm{Cu}_{2} \mathrm{O}$ oxygen buffers, and new data for the W-WO2 buffer; Contrib. Mineral. Petrol. 114(3) 296-314.

Otten M T 1984 The origin of brown hornblende in the Artfjället gabbro and dolerites; Contrib. Mineral. Petrol. 86(2) 189-199.

Paterson S R, Vernon R H and Tobisch O T 1989 A review of criteria for the identification of magmatic and tectonic foliations in granitoids; J. Struct. Geol. 11(3) 349363.

Paterson S R, Fowler T K Jr, Schmidt K L, Yoshinobu A S, Semele Yuan E and Miller R B 1998 Interpreting magmatic fabric pattern in plutons; Lithos 4453 82.

Pitcher W S 1997 The nature and origin of granite; 2nd edn, Chapman \& Hall, London, 387p.

Ridley J 1992 On the origins and tectonic significance of the charnockite suite of the Archaean Limpopo Belt, Northern Marginal Zone, Zimbabwe; Precamb. Res. 55 407-427.

Ridolfi F and Renzulli A 2012 Calcic amphiboles in calc-alkaline and alkaline magmas: Thermobarometric and chemometric empirical equations valid up to $1130^{\circ} \mathrm{C}$ and $2.2 \mathrm{GPa}$; Contrib. Mineral. Petrol. 163(5) 877-895.

Ridolfi F, Renzulli A and Puerini M 2010 Stability and chemical equilibrium of amphibole in calc-alkaline magmas: An overview, new thermobarometric formulations and application to subduction-related volcanoes; Contrib. Mineral. Petrol. 160(1) 45-66. 
Rosenberg C L 2004 Shear zones and magma ascent: A model based on a review of the Tertiary magmatism in the Alps; Tectonics 23.

Schmidt M W 1992 Amphibole composition in tonalite as a function of pressure: An experimental calibration of the Al-in-hornblende barometer; Contrib. Mineral. Petrol. 110(2-3) 304-310.

Sen S 1953 Origin of charnockitic assemblages of east Manbhum, Bihar; Am. J. Sci. 251(5) 388-392.

Sen S 1956 Structures of the porphyritic granite and associated metamorphic rocks of east Manbhum, Bihar, India; Bull. Geol. Soc. Am. 67(5) 647-670.

Sen S 1959 Mineralogenetic trends in the evolution Metamorphic rocks and origin of granites in E. Manbhum; Proc. Nat. Inst. Sci. Ind. 25 118-138.

Shabani A A, Lalonde A E and Whalen J B 2003 Composition of biotite from granitic rocks of the Canadian Appalachian orogen: A potential tectonomagmatic indicator; Can. Mineral. 41(6) 1381-1396.

Shelley D 1993 Igneous and metamorphic rocks under the microscope; Chapman \& Hall, London, p. 445.

Singh S P 1998 Precambrain stratigraphy of Bihar - An overview; In: The Indian Precambrian (ed.) Paliwal B S, Scientific Publishers India, Jodhpur, pp. 376-408.

Speer J A 1987 Evolution of magmatic AFM mineral assemblages in granitoid rocks: The hornblende + melt=biotite reaction in the Liberty Hill pluton, South Carolina; $A m$. Mineral. 72 9-10.

Stein E and Dietl C 2001 Hornblende thermobarometry of granitoids from the Central Odenwald (Germany) and their implications for the geotectonic development of the Odenwald; Mineral. Petrol. 72(1-3) 185-207.

Streckeisen A 1976 To each plutonic rock its proper name; Earth Sci. Rev. 12(1) 1-33.

Vernon R H 2004 A Practical Guide to Rock Microstructure; Cambridge University Press, UK.

Vyhnal C R, McSween H Y and Speer J A 1991 Hornblende chemistry in southern appalachian granitoids: Implications for aluminum hornblende thermobarometry and magmatic epidote stability; Am. Mineral. $\mathbf{7 6}$ $167-188$.

Wones D R 1972 Stability of biotite - A reply; Am. Mineral. 57(1-2) 316.

Wones D R 1981 Mafic silicates as indicators of intensive variables in granitic magmas; Mining Geol. 31(168) 191212.

Wones D R 1989 Significance of the assemblage titanite + magnetite + quartz in granitic rocks; Am. Minerl. $\mathbf{7 4}$ 744-749.

Wones D R and Eugster H P 1965 Stability of biotite: Experiment, theory, and application; Am. Mineral. 50 1228-1272. 